Prepared in cooperation with the city of Wichita, Kansas

\title{
Status of Ground-Water Levels and Storage Volume in the Equus Beds Aquifer Near Wichita, Kansas, January 2003-January 2006
}

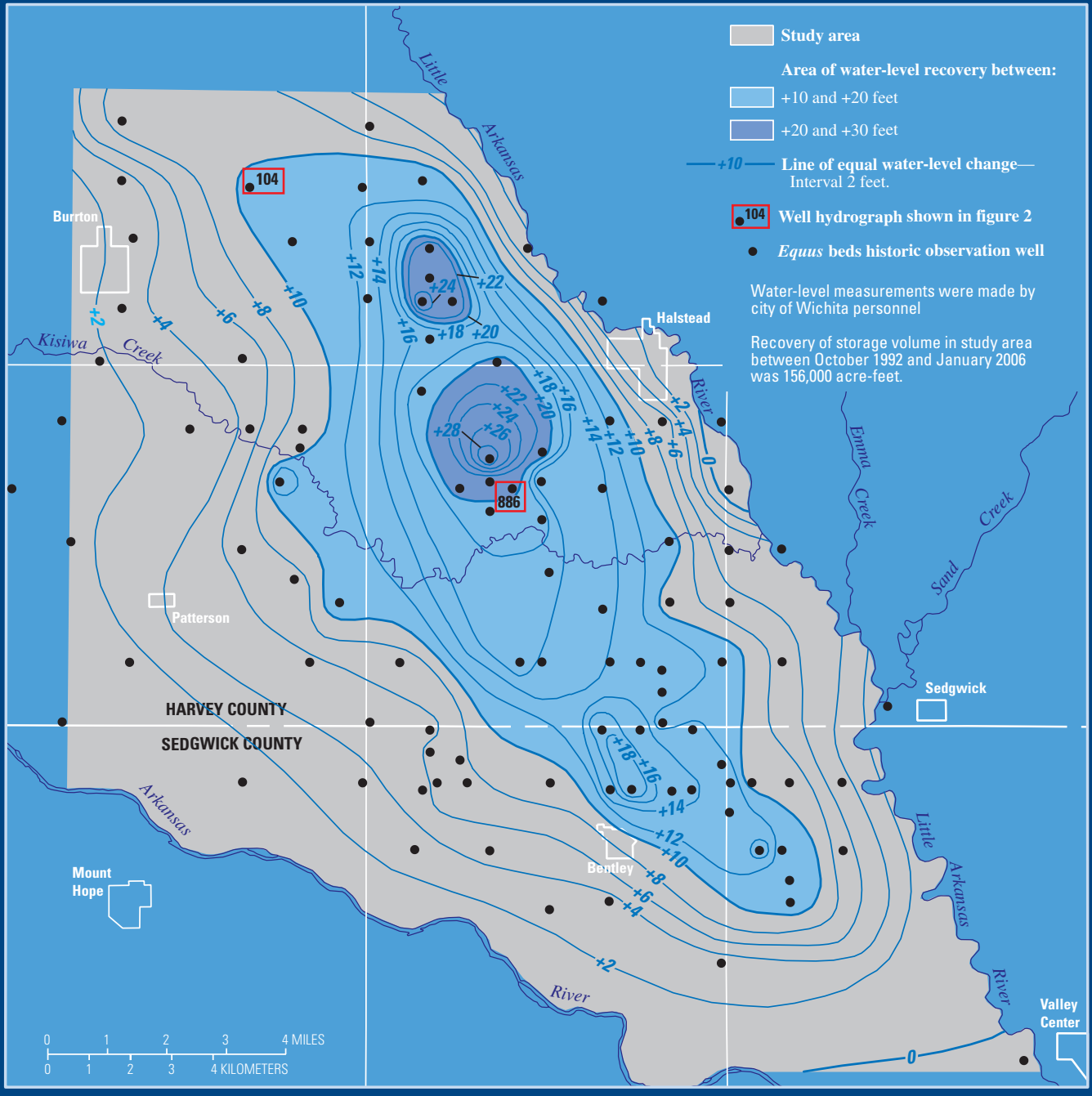

Scientific Investigations Report 2006-5321 



\section{Status of Ground-Water Levels and Storage Volume in the Equus Beds Aquifer Near Wichita, Kansas, January 2003-January 2006}

By Cristi V. Hansen

Prepared in cooperation with the city of Wichita, Kansas

Scientific Investigations Report 2006-5321 


\title{
U.S. Department of the Interior DIRK KEMPTHORNE, Secretary
}

\author{
U.S. Geological Survey \\ Mark D. Myers, Director
}

\section{U.S. Geological Survey, Reston, Virginia: 2007}

For product and ordering information:

World Wide Web: http://www.usgs.gov/pubprod

Telephone: 1-888-ASK-USGS

For more information on the USGS--the Federal source for science about the Earth, its natural and living resources, natural hazards, and the environment:

World Wide Web: http://www.usgs.gov

Telephone: 1-888-ASK-USGS

Any use of trade, product, or firm names is for descriptive purposes only and does not imply endorsement by the U.S. Government.

Although this report is in the public domain, permission must be secured from the individual copyright owners to reproduce any copyrighted materials contained within this report.

Suggested citation:

Hansen, C.V., 2007, Status of ground-water levels and storage volume in the Equus Beds aquifer near Wichita, Kansas, January 2003-January 2006: U.S. Geological Survey Scientific Investigations Report 2006-5321, 34 p. 


\section{Contents}

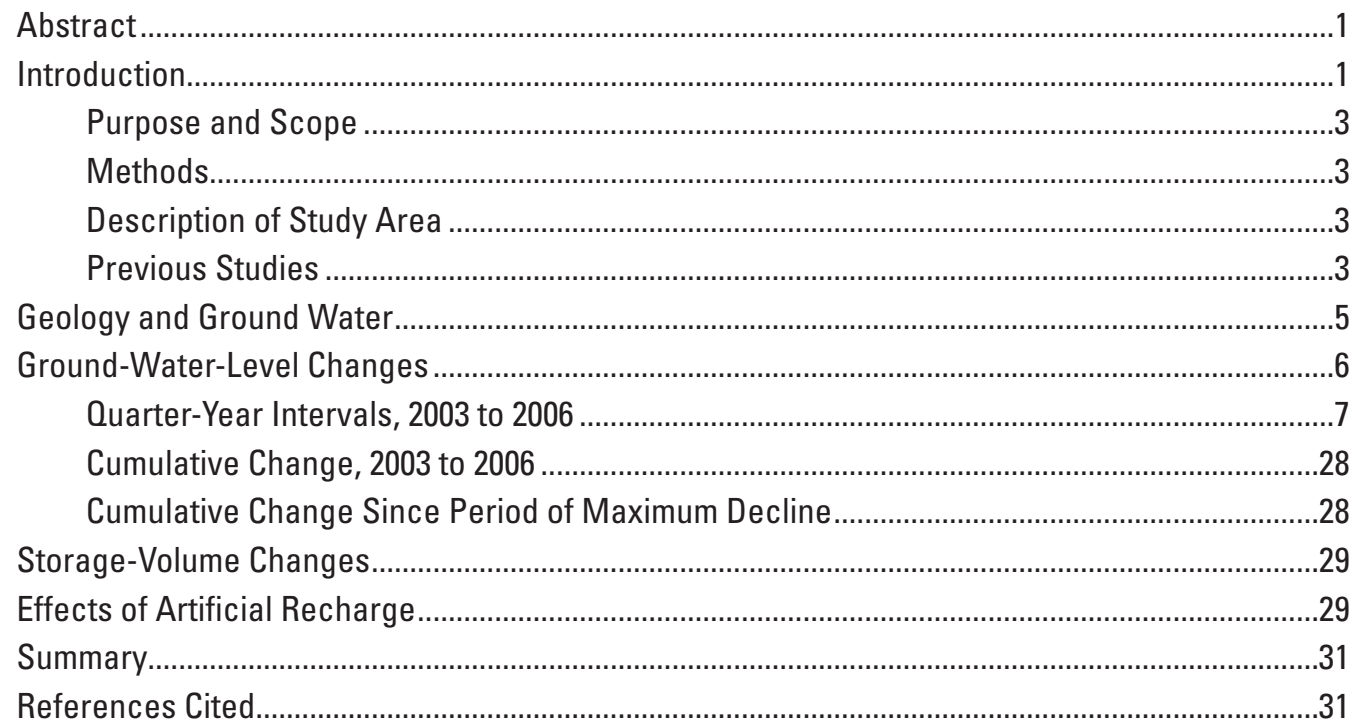

\section{Figures}

1. Maps showing location of study area near Wichita, south-central Kansas .....................2

2. Graphs showing relation of precipitation, water use for agricultural irrigation and by city of Wichita for public supply, and water-level altitudes in observation wells 104 and 886 and Equus Beds aquifer storage-volume change in study area, 1938-January 2006......4

3. Generalized geologic section ....................................................................................

4-6. Maps showing water-level altitudes in Equus Beds aquifer in study area:

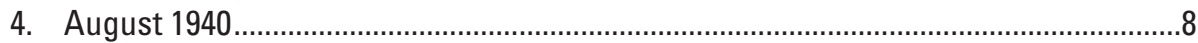

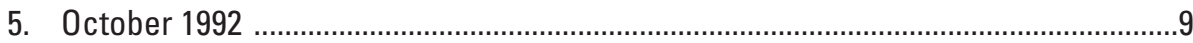

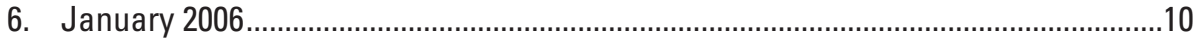

7-23. Maps showing water-level changes in Equus Beds aquifer in study area:

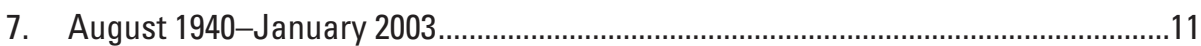

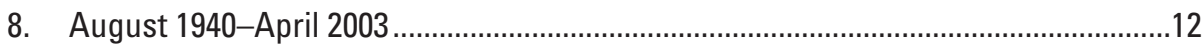

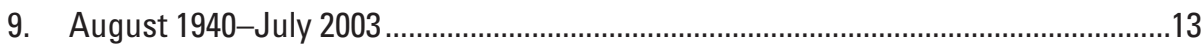

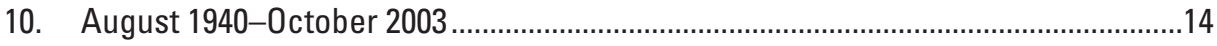

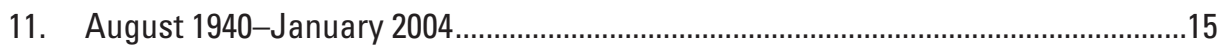

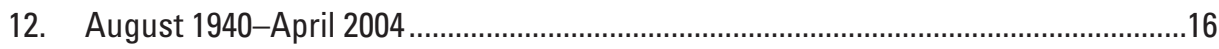

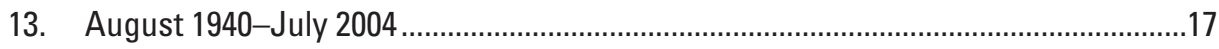

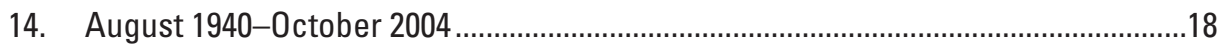

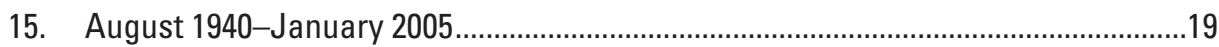

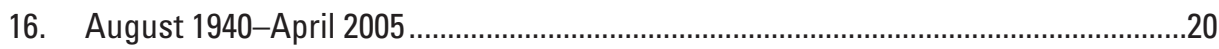

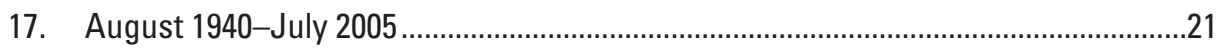

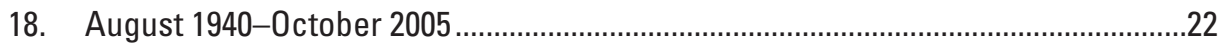

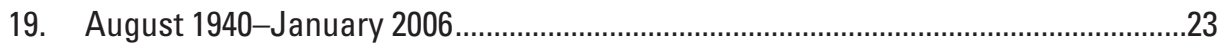




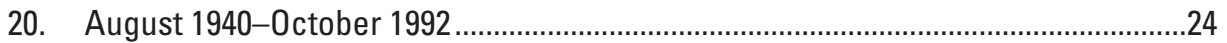

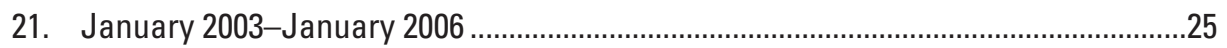

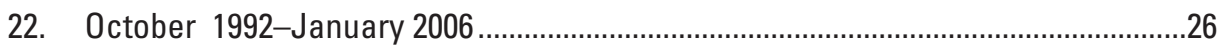

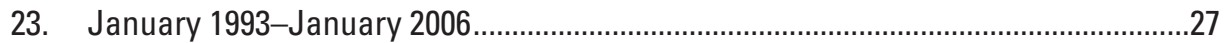

\section{Table}

1. Storage-volume changes in Equus Beds aquifer near Wichita, south-central Kansas, August 1940-January 2006.

\section{Conversion Factors, Abbreviations, and Datums}

\begin{tabular}{lcl}
\hline Multiply & By & To obtain \\
\hline & Length & \\
\hline inch (in.) & 25.4 & millimeter $(\mathrm{mm})$ \\
foot (ft) & 0.3048 & meter $(\mathrm{m})$ \\
mile (mi) & 1.609 & kilometer $(\mathrm{km})$ \\
\hline & Area & \\
\hline square mile $\left(\mathrm{mi}^{2}\right)$ & 2.590 & square kilometer $\left(\mathrm{km}^{2}\right)$ \\
\hline & Volume & \\
\hline acre-foot (acre-ft) & 1,233 & cubic meter $\left(\mathrm{m}^{3}\right)$ \\
\hline & Flow rate & \\
\hline acre-foot per year (acre-ft/yr) & 1,233 & cubic meter per year $\left(\mathrm{m}^{3} / \mathrm{yr}\right)$ \\
inch per year (in/yr) & 25.4 & millimeter per year $(\mathrm{mm} / \mathrm{yr})$ \\
\hline
\end{tabular}

Temperature in degrees Celsius $\left({ }^{\circ} \mathrm{C}\right)$ may be converted to degrees Fahrenheit ( $\left.{ }^{\circ} \mathrm{F}\right)$ as follows:

$$
{ }^{\circ} \mathrm{F}=\left(1.8 \times{ }^{\circ} \mathrm{C}\right)+32 .
$$

Temperature in degrees Fahrenheit $\left({ }^{\circ} \mathrm{F}\right)$ may be converted to degrees Celsius $\left({ }^{\circ} \mathrm{C}\right)$ as follows:

$$
{ }^{\circ} \mathrm{C}=\left({ }^{\circ} \mathrm{F}-32\right) / 1.8 .
$$

Prior to April 2000, vertical coordinate information is referenced to the National Geodetic Vertical Datum of 1929 (NGVD 29). For April 2000 and after, vertical coordinate information is referenced to the North American Vertical Datum of 1988 (NAVD 88). NAVD 88 vertical coordinates are about $0.5 \mathrm{ft}$ higher than NGVD vertical coordinates in the part of south-central Kansas discussed in this report.

Horizontal coordinate information is referenced to the North American Datum of 1983 (NAD 83).

Altitude, as used in this report, refers to distance above the vertical datum. 


\title{
Status of Ground-Water Levels and Storage Volume in the Equus Beds Aquifer Near Wichita, Kansas, January 2003-January 2006
}

\author{
By Cristi V. Hansen
}

\section{Abstract}

The Equus Beds aquifer northwest of Wichita, Kansas, was developed to supply water to Wichita residents and for irrigation in south-central Kansas. Ground-water pumping for city and agricultural use from the aquifer caused water levels to decline in a large part of the aquifer northwest of Wichita. Irrigation pumpage in the area increased substantially during the 1970s and 1980s and accelerated water-level declines. A period of water-level rises associated with greater-than-average precipitation and decreased city pumpage from the area began in 1993. An important factor in the decreased city pumpage was increased use of Cheney Reservoir as a watersupply source by the city of Wichita; as a result, city pumpage from the Equus Beds aquifer during 1993-2005 decreased to quantities similar to those pumped in the 1940s and went from being about 60 percent to about 40 percent of Wichita's water usage. Since 1995, the city also has been investigating the use of artificial recharge in the study area to meet future water-supply needs and to protect the aquifer from the intrusion of saltwater from sources to the west.

During January 2006, the direction of ground-water flow in the Equus Beds aquifer in the area was generally from west to east, similar to the direction prior to development of the aquifer. Water-level changes since 1940 for the period January 2003-January 2006 ranged from a decline of more than 36 feet to a rise of more than 2 feet. Almost all wells in the area had small cumulative water-level rises from January 2003 to January 2006 and larger rises from October 1992 (period of maximum storage loss) to January 2006. The water-level rises from October 1992 to January 2006 probably are due principally to decreases in city pumpage, with increases in recharge due to increased precipitation during the period also a contributing factor. Irrigation pumpage increased during the period, so irrigation did not contribute to the rises in water levels between the beginning and end of the period. The storage volume change from October 1992 to January 2006 represents a recovery of about 55 percent of the storage volume previously lost between August 1940 and October 1992.

\section{Introduction}

The Wichita well field in the Equus Beds aquifer in southwestern Harvey County and northwestern Sedgwick County was developed to supply water to residents of Wichita and for irrigation in the study area in south-central Kansas (fig. 1). On September 1, 1940, Wichita began pumping from 25 wells completed in the aquifer in the central part of the study area (Stramel, 1956) (the central part of the study area is identified in fig. 1), and by 1959, there were 55 wells in use by the city of Wichita (Stramel, 1967). Ground-water pumpage from the aquifer for city and agricultural use has caused water levels to decline in a large part of the study area. A substantial decline in water levels occurred from 1940 until the drought of the 1950s ended in early 1957 (Stramel, 1967). In 1965, the city of Wichita began using water from Cheney Reservoir (Stramel, 1967) in addition to water from the Equus Beds aquifer and thus reduced the amount of water that would have been pumped from the Equus Beds aquifer. Ground-water pumpage for irrigation in the study area increased substantially during the 1970s and 1980s and accelerated water-level declines (Spinazola and others, 1985; Myers and others, 1996; Aucott and Myers, 1998). Most of the water-level declines can be attributed to ground-water pumpage; however, climatic conditions (and thus recharge to the Equus Beds aquifer) also have affected water levels.

The Equus Beds Groundwater Management District No. 2 (GMD2) was formed in 1975 as part of the effort to balance the factors affecting water levels in the Equus Beds aquifer, to efficiently manage and optimize the use of water from the aquifer, and to preserve the aquifer for future generations. GMD2 has developed a management program that is based on the "aquifer safe yield principle." The aquifer safe yield principle limits the annual amount of ground-water pumpage to the annual amount of ground-water recharge as noted in the management program of GMD2 (Equus Beds Groundwater Management District No. 2, 1995).

Since 1995, the city of Wichita, in cooperation with the U.S. Geological Survey (USGS), has been investigating the potential for using artificial ground-water recharge in the 


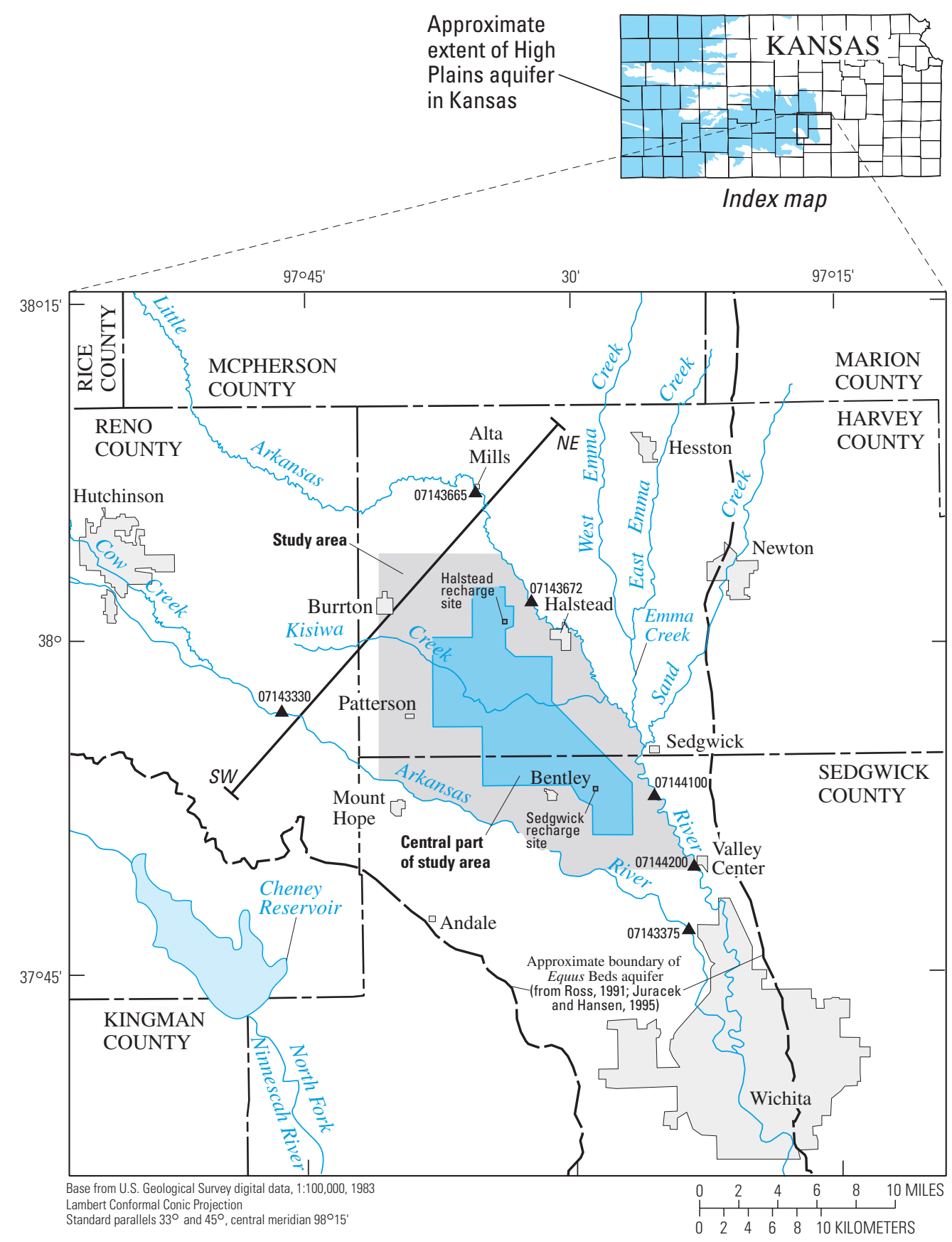

EXPLANATION

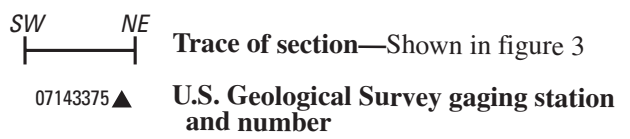

Figure 1. Location of study area near Wichita, southcentral Kansas (modified from Aucott and Myers, 1998).

study area to meet future water-supply needs and to protect the aquifer from the intrusion of saltwater from natural and human-related sources to the west (Warren and others, 1995). Other entities involved with this effort include GMD2 (Halstead, Kansas), Bureau of Reclamation (U.S. Department of the Interior), U.S. Environmental Protection Agency, various Kansas State agencies, Burns and McDonnell Engineering Consultants (Kansas City, Missouri), and Mid-Kansas Engineering Consultants (Wichita, Kansas).
The social and economic importance of ground-water resources and the potential changes that artificial recharge may bring to the aquifer prompted a cooperative study between the USGS and the city of Wichita. The study documented changes in historical hydrologic and water-quality conditions and the probable causes of these changes in the study area, developed a baseline condition for evaluating the effects of artificial recharge on ground-water levels in the aquifer, and reviewed changes in the ground-water flow system. 
The USGS and the city of Wichita have worked cooperatively since 1940 in evaluating the Equus Beds aquifer and its interaction with streams in the area to further the understanding of the entire hydrologic system and to provide information to aid local decisionmaking. The understanding gained from this cooperative study of the hydrologic system and the Equus Beds aquifer helps contribute to the wise management of water resources where similar hydrologic conditions exist elsewhere. This report is prepared in cooperation with the city of Wichita.

\section{Purpose and Scope}

The purpose of this report is to describe ground-waterlevel and storage-volume changes in the Equus Beds aquifer northwest of Wichita during January 2003 to January 2006 as compared with predevelopment (1940) ground-water levels and to update historical information related to changes in the aquifer storage since 1940. Maps of ground-water-level measurements and water-level changes are presented. Two hydrographs of ground-water levels were selected to show historical water-level variations. Historical water-use and climate information also are presented. Information in this report can be used to document and improve understanding of the effects of climate, water-use, and water-resource management practices on water supplies in the Equus Beds aquifer, an important source of water for the city of Wichita and the surrounding area.

\section{Methods}

Extensive information is available to describe hydrologic conditions in the study area. Water-level data have been collected periodically from more than 100 wells by city of Wichita personnel using standard water-level measurement techniques that are similar to USGS methods described in Stallman (1971). Data collection began just prior to the beginning of city pumpage from the aquifer in the study area in 1940; water levels in most wells have been measured at least quarterly. These data are on file in paper and electronic form with the city of Wichita Water and Sewer Department in Wichita, Kansas, and are stored by the USGS in the National Water Information System (NWIS) database and are available at the following URL: http://waterdata.usgs.gov/ks/nwis

During 2001 and 2002, 38 pairs of areal index wells in and near the study area were installed by Burns and McDonnell Engineering Consultants and Clarke Well Equipment, Incorporated (Great Bend, Kansas) for the city of Wichita. Each pair of areal index wells consists of a well completed in the upper part of the aquifer and another well completed in the lower part of the aquifer. These wells were designed for use by the city to monitor the water quality and water levels in the aquifer throughout the study area and any changes that might occur as a result of the planned artificial recharge project. These wells also were used to determine if there are any water-quality differences between the shallow and deep parts of the aquifer (Andrew Ziegler, U.S. Geological Survey, oral commun., September 2003). As water levels also can be measured in these wells, the wells were added to the water-level monitoring network in the study area in 2002. Water levels in these index wells are measured quarterly by GMD2 and occasionally by the USGS; all index well water-level measurements used in this report were measured by GMD2. The data collected by the USGS are stored in the NWIS database and are available at the following URL: http://waterdata.usgs.gov ks/nwis The data collected by GMD2 are stored in the Kansas Geological Survey's (KGS's) Water Information Storage and Retrieval Database (WIZARD) and are available at the following URL: http://www.kgs.ku.edu/Magellan/WaterLevels/index. htm

\section{Description of Study Area}

The study area (fig. 1) includes about $165 \mathrm{mi}^{2}$ and is located in Harvey and Sedgwick Counties northwest of Wichita, Kansas. The study area is in the Arkansas River section of the Central Lowlands physiographic province (Schoewe, 1949). There is little topographic relief in the study area. For the most part, the land surface slopes gently toward the major streams in the study area. The study area is bounded on the southwest by the Arkansas River and on the northeast by the Little Arkansas River. The central part of the study area (fig. 1), which is referred to throughout the report, is the historic center of pumping in the study area and includes wells that supply water to the city of Wichita and for irrigation.

South-central Kansas has a continental climate that is characterized by large variations in seasonal temperatures, moderate precipitation, and windy conditions. In Wichita, Kansas, long-term daily average temperatures for 1971-2000 ranged from $30.2^{\circ} \mathrm{F}$ in January to $81.0^{\circ} \mathrm{F}$ in July (National Oceanic and Atmospheric Administration, 2002b). The longterm annual average precipitation for 1940-2005 at weather stations near the study area (at Halstead, Hutchinson, Mount Hope, Newton, Sedgwick, and Wichita) is 31.35 in. (National Oceanic and Atmospheric Administration, 1998-2005b,) (fig. 2A). Precipitation was equal to or greater than the longterm annual average during 2003 through 2005.

\section{Previous Studies}

Water-level data have been collected periodically by the city of Wichita in the study area since 1940 and are on file with the city and the USGS in Wichita and Lawrence, Kansas, respectively. Water-level data also have been collected by GMD2 since 1978 from wells completed in the Equus Beds aquifer (Equus Beds Groundwater Management District No. 2, 1995). Annual water-level data for the High Plains aquifer (fig. 1), which includes the Equus Beds aquifer, have been collected since 1937 by the Kansas Department of Agriculture (Division of Water Resources), USGS, and KGS. The data on file with the USGS in Lawrence, Kansas, are stored in 
A. Precipitation

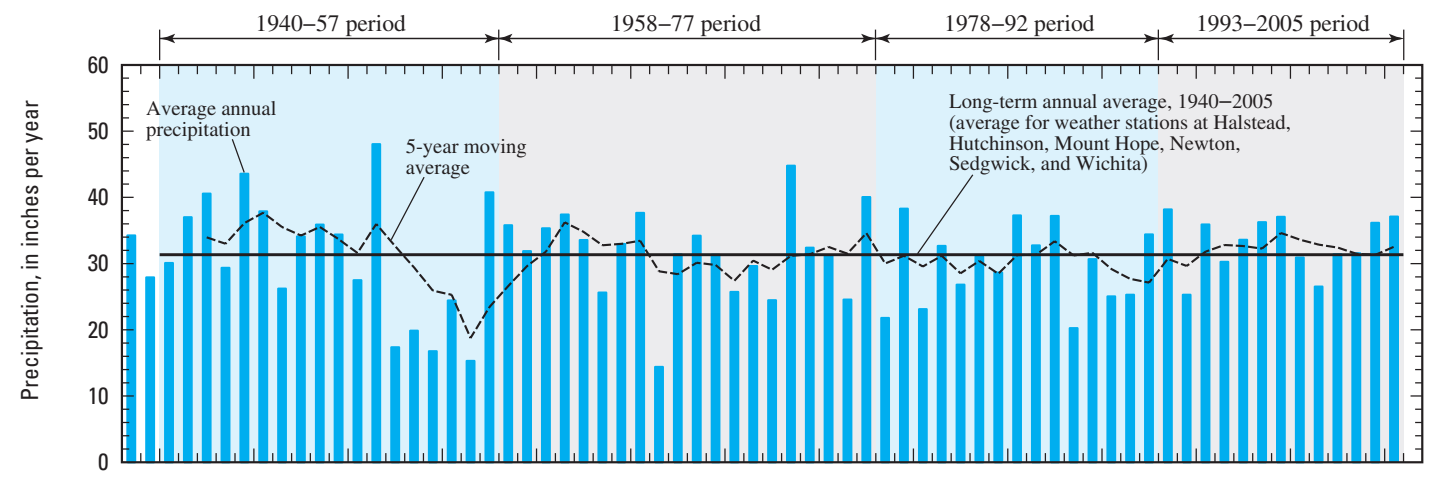

B. Water use for agricultural irrigation and by city of Wichita for public supply

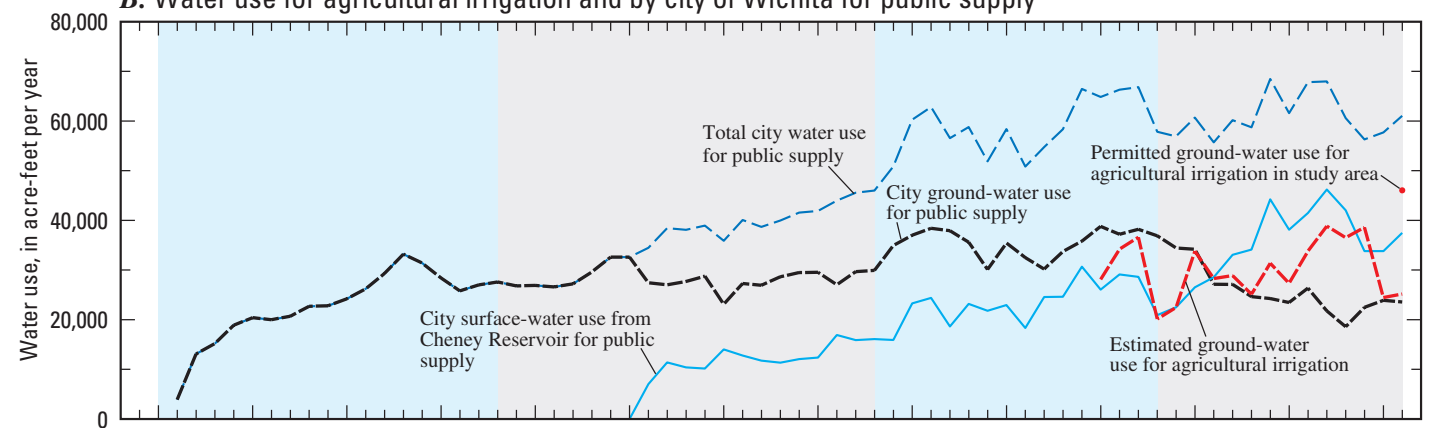

C. Water-level altitudes in observation wells 104 and 886 and Equus Beds aquifer storage-volume change in study area

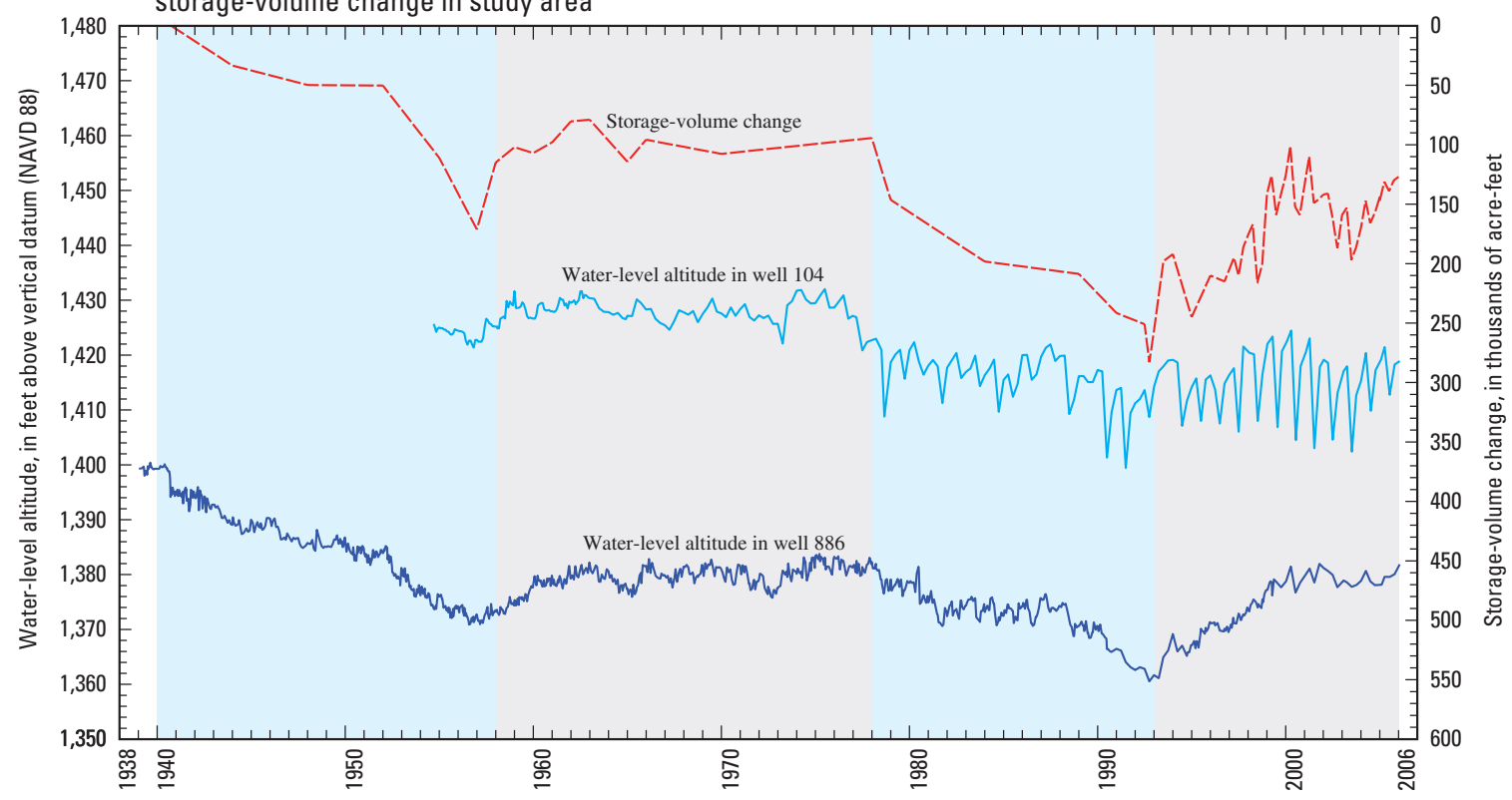

Figure 2. Relation of $(A)$ precipitation, $(B)$ water use for agricultural irrigation and by city of Wichita for public supply, and $(C)$ water-level altitudes in observation wells 104 and 886 and Equus Beds aquifer storage-volume change in study area, 1938-January 2006 (modified from Aucott and others, 1998). Source: (A) precipitation data from National Oceanic and Atmospheric Administration (1998-2005b); (B) water-use data from Stramel (1956, 1967), Gerald T. Blain (city of Wichita, written commun., 2000), Joan Kenny (U.S. Geological Survey, written commun., 2000, 2003, and 2006), Brownie Wilson (Kansas Water Office, written commun., 2000), and Kelly Emmons (Kansas Department of Agriculture, Division of Water Resources, written commun., 2003 and 2006); $(C)$ water-level altitude data from Stramel $(1956,1967)$ and from data collected by city of Wichita, Equus Beds Groundwater Management District No. 2, and on file with U.S. Geological Survey, Lawrence, Kansas. Location of observation wells is shown in figure 5. Storage-volume changes from Stramel (1956, 1967), Aucott and Myers (1998), Aucott and others (1998), Hansen and Aucott (2001, 2004), and data on file with U.S. Geological Survey in Lawrence, Kansas. 
the USGS NWIS database and are available at http://water data.usgs.gov/ks/nwis/gh; data on file with the KGS are stored in their WIZARD database (Kansas Geological Survey, 2002). Historical and near-real-time data and reports associated with the Equus Beds Ground-Water Demonstration Recharge Project (Ziegler and others, 1999) are available at http://ks.water. usgs.gov/Kansas/studies/equus

Williams and Lohman (1949), Stramel (1956, 1967), Lane and Miller (1965a), and Leonard and Kleinschmidt (1976) have published water levels and water-level decline maps for the study area; Williams and Lohman (1949) and Stramel (1956) also published water-level altitude maps for the study area. Ross and others (1997) noted water-level rises in the Equus Beds aquifer from 1993 to 1997 and attributed them largely to decreases in withdrawals by the city of Wichita. Aucott and Myers (1998), Aucott and others (1998), and Hansen and Aucott $(2001,2004)$ published water-leveldecline maps for the study area and discussed the changes in storage volume for noteworthy past and recent periods of time. Myers and others (1996) evaluated the hydrologic interaction between the Arkansas River and the Equus Beds aquifer in the study area. Water-level data for the Equus Beds and High Plains aquifers have been compiled and mapped recently in Kansas by Bohling and Wilson (2004, 2005, and 2006), Laflen and Miller (2003, 2004, and 2005), Mitchell and others (1993 and 1994), Olea and Davis (2003), Woods and others $(1994,1995,1997,1998,1999$, and 2000), Woods and Schloss (1996), and Woods and Sophocleous (2002 and 2004) and regionally by McGuire and Sharpe (1997), McGuire and Fischer (1999), McGuire (2001, 2003, 2004a, 2004b), and McGuire and others (2003).

\section{Geology and Ground Water}

Quaternary deposits occur throughout the study area primarily as alluvial deposits. These alluvial deposits, known locally as the Equus beds, are as much as $250 \mathrm{ft}$ thick in the study area (fig. 3). The Equus beds consist primarily of sand and gravel interbedded with clay or silt but locally may consist primarily of clay with thin sand and gravel layers (Lane and Miller, 1965a; Myers and others, 1996). The middle part of the deposits generally has more fine-grained material than the lower and upper parts (Lane and Miller, 1965b; Myers and others, 1996).

The Wellington Formation of Permian age underlies the Quaternary deposits in the study area and forms the bedrock confining unit below these deposits. The Wellington Formation is about $700 \mathrm{ft}$ thick (Bayne, 1956) and consists of three members - the lower anhydrite member, about $200 \mathrm{ft}$ thick; the Hutchinson Salt Member, about $300 \mathrm{ft}$ thick; and the upper shale member, about $200 \mathrm{ft}$ thick (Myers and others, 1996). Dissolution of the Hutchinson Salt Member resulted in subsidence of the overlying upper shale member, formation of low areas in the bedrock, and concurrent accumulation of alluvial

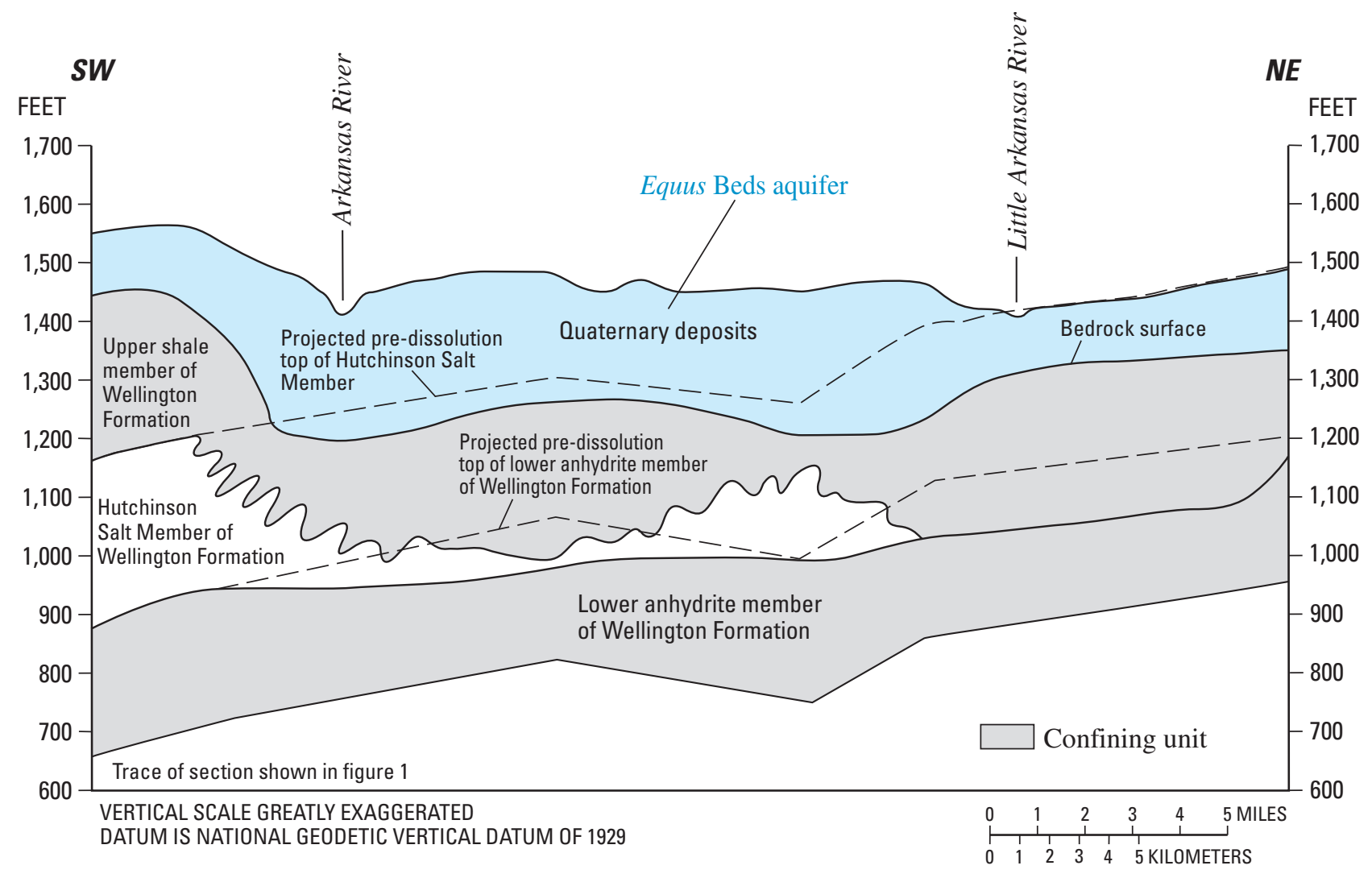

Figure 3. Generalized geologic section (from Leonard and Kleinschmidt, 1976; Myers and others, 1996). 
deposits that now compose the Equus Beds aquifer (fig. 3) (Myers and others, 1996).

The Equus Beds aquifer is the easternmost extension of the High Plains aquifer in Kansas (Stulken and others, 1985; Hansen and Aucott, 2001). The Equus beds are an important source of ground water because of the generally shallow depth to the water table, the large saturated thickness, and generally good water quality. Near the Arkansas River, the water table may be as little as $10 \mathrm{ft}$ below land surface. Farther from the Arkansas River and near the Little Arkansas River, the water table is at a greater depth, depending on the altitude of the land surface and the amount of water-level decline that has been caused by ground-water withdrawals. The maximum saturated thickness of the Equus Beds aquifer within the study area, almost $250 \mathrm{ft}$, is near the Arkansas River and corresponds to the lowest areas of the underlying bedrock surface (Spinazola and others, 1985). Assuming the Equus Beds aquifer in the study area is an average of $100 \mathrm{ft}$ thick and about 20 percent of the aquifer volume stores water available for use, then the estimated storage volume in the study area is about $2,100,000$ acre-ft.

\section{Ground-Water-Level Changes}

Ground-water-level declines can result from a combination of factors-pumpage, decreased recharge resulting from less-than-average precipitation, and other factors. Droughts, such as occurred during 1952-56 and 1988-92 (fig. 2A), tend to decrease the amount of recharge available and increase demand for and thus pumpage of ground water (fig. 2B), resulting in increased water-level declines (fig. 2C). Periods of greater-than-average rainfall, such as occurred in 1957-62 (fig. $2 A$ ), tend to increase the amount of recharge available and decrease the demand for and thus pumpage of ground water (fig. $2 B$ ), resulting in water-level rises (fig. $2 C$ ). If the waterlevel declines or rises are large enough, they may alter locally the direction of ground-water flow.

Description of noteworthy periods of water-level change in the study area is facilitated by the use of hydrographs of water levels in observation wells 104 and 886 (fig. $2 C$; see figure 5 later in this section). The hydrograph of well 104 serves as a representative descriptor of agricultural irrigation effects near the northern edge of the study area; the hydrograph of well 886 serves as a representative descriptor of historical water-level changes in an area of maximum waterlevel decline near the historic center of pumping by the city of Wichita in the central part of the study area.

Aucott and Myers (1998) identified four noteworthy periods of water-level change (fig. 2C): 1940-57, the initial water-level decline period when pumpage began in the study area, which includes a phase of accelerated declines in the mid-1950s coinciding with drought conditions; 1958-77, a period of general equilibrium with relatively stable city pumpage and water levels and increasing irrigation pumpage that became significant in the late 1970s; 1978-92, another period of water-level declines and increased city and irrigation pumpage due to increased demands and drought conditions; and 1993-98, a period of water-level rises associated with generally greater-than-average precipitation and decreased city pumpage. The first three periods have been well documented by Aucott and Myers (1998) and will not be described in this report. The fourth period - the period of water-level rises seen by Aucott and Myers (1998) during 1993-98 — was noted by Hansen and Aucott (2004) as continuing through April 2000 and possibly to January 2003 when the last reporting period ended. Despite a slight water-level decline during 2001-03, water levels in wells in the study area (for example, wells 104 and 886 in figure $2 C$ ) have remained relatively high, indicating this period of water-level rises that began in 1993 continued through the current reporting period (January 2003 to January 2006).

The consistently large seasonal water-level variations in well 104 probably are due to agricultural irrigation pumpage. Irrigation water-use amounts prior to 1989 are not plotted in figure $2 B$ because of incomplete reporting of water-use data before 1989 (Lane Letourneau, Kansas Department of Agriculture, Division of Water Resources, oral commun., August 2 , 2002). Estimated water use for agricultural irrigation in the study area in 2005 was about two-thirds of what is permitted by the State of Kansas (Kelly Emmons, Kansas Department of Agriculture, Division of Water Resources, written commun., August 21, 2006) (fig. 2B); thus, increased irrigation water use in the study area could become a more significant factor, especially during future dry years.

The use of ground-water hydrographs along with the use of maps of water-level altitudes and of water-level changes and the use of tables and graphs of changes in storage volume can provide a more complete picture of changes in hydrologic conditions than the use of any one of these graphic tools. Hydrographs of individual wells are important for indicating changes over time at a specific point and can be used to infer the effects of water-level changes at that point. Such effects could include dewatered shallow wells or increased pumping costs to lift water from greater depths. Water-level-altitude maps show the gradient and direction of ground-water flow over a large area at a particular time. A single water-level-altitude map cannot indicate location or extent of the areas affected by waterlevel declines or rises or how great these declines or rises are. However, water-level-change maps can be used to illustrate the location, extent, and magnitude of water-level declines and rises. Tables and graphs showing changes in storage volume, which are derived from water-level-change maps and represent a decrease (or increase) in the ground-water resource available for use, are a good measure of the cumulative effects of pumping and climatic conditions on the aquifer.

To illustrate water-level conditions for selected periods, previously published water-level-altitude maps for August 1940 (Stramel, 1956; Aucott and Myers, 1998) and October 1992 (Hansen and Aucott, 2001) were used in addition to the water-level-altitude map for January 2006 that was constructed 
for this report (figs. 4, 5, and 6). Available water-level data from wells in the study area and surface-water data from gaging stations in and near the study area were used to construct the water-level-altitude map for January 2006 (fig. 6). In addition to ground-water-level measurements from historic Equus beds observation wells, figure 6 also includes water-level-altitude measurements from the selected areal index wells. For mapping purposes, the water levels from the shallow well at the site of each pair of areal index wells were used, except at the three most northwesterly pairs of areal index well sites in T. 23 S., R. 3 W.; water levels from the deep wells in these three pairs were used instead because they best represent the part of the aquifer open to the historic observation wells in this part of the study area. The selection of the wells used for mapping purposes from each of the 38 pairs of areal index wells was previously described in Hansen and Aucott (2004). Average daily surface-water-altitude measurements computed for January 25, 2006, from data automatically collected by equipment at USGS gaging stations (stations 07143330 , 07143375, 07143665, 07143672, 07144100, and 07144200) on the Arkansas and Little Arkansas Rivers in and near the study area (fig. 1) were used to estimate the surface-water altitude along these streams as depicted in figure 6 . The average daily surface-water altitudes for January 25, 2006, are shown at the three gaging stations on the Little Arkansas River that are in the study area (fig. 6); no gaging stations on the Arkansas River are in the study area (fig. 1). January 25, 2006, was chosen for the surface-water altitudes shown in figure 6 because it is the midpoint point of the period during which ground-water levels used for this figure were measured.

Figures 4, 5, and 6, respectively, illustrate conditions during predevelopment (August 1940), record low water levels in October 1992, and current (January 2006) conditions. Prior to pumpage from the Equus Beds aquifer in 1940, near-predevelopment conditions existed in the study area (Williams and Lohman, 1949; Aucott and Myers, 1998). The August 1940 water-level-altitude map from Stramel (1956) that was modified by Aucott and Myers (1998) (fig. 4) shows that ground water flowed generally from west to east and discharged to the Little Arkansas River. Water-level-altitude maps for August 1940 and January 1955 (Stramel, 1956); for January 1957, January 1970, January 1993, and January 1998 (Aucott and Myers, 1998); for January 1997 (Aucott and others, 1998); for October 1992 and January 2000 (Hansen and Aucott, 2001); for April 2000 and January 2003 (Hansen and Aucott, 2004); and January 2006 (fig. 6) indicate that, following development, ground-water flow remained from west to east, but that between the central part of the study area and the Little Arkansas River and in the vicinity of Halstead and Sedgwick, the flow generally became more southerly and more parallel to the river.

Water-level change maps were constructed from available water-level data to show changes between August 1940 (predevelopment) and quarter-year intervals from January 2003 to January 2006 (figs. 7-19), between August 1940 and October 1992 (fig. 20), between January 2003 and January 2006 (fig. 21), between October 1992 and January 2006 (fig. 22), and between January 1993 and January 2006 (fig. 23). The August 1940 to October 1992 period (fig. 20) was selected as representative of the cumulative change between predevelopment and the period of maximum water-level decline (Hansen and Aucott, 2001). The January 2003 to January 2006 and the October 1992 to January 2006 periods (figs. 21 and 22, respectively) were selected as representative, respectively, of the cumulative change since the last report on water levels in the area (Hansen and Aucott, 2004) and of the cumulative change since the period of maximum water-level decline (Hansen and Aucott, 2001). Because January-to-January measurements can be used to minimize the effect of seasonal factors on water-level changes for year-to-year comparisons, a map of water-level changes for the period January 1993 to January 2006 (fig. 23) was included as an alternate representation of the cumulative changes since the period of maximum waterlevel decline.

In constructing figures 7-20 and similar maps in recent reports showing water-level changes since August 1940 (Aucott and Myers, 1998; Aucott and others, 1998; Hansen and Aucott, 2001, 2004), if a 1940 water-level measurement did not exist for a well in the study area, one was interpolated from the August 1940 water-level-altitude map (fig. 4). Starting in April 2005, quarter-year-interval water-level-change maps were constructed without using the 12 Equus beds historic observation wells that are near Equus beds areal index wells. During the preceding 3 years, water-level differences that ranged from -17.58 to $7.25 \mathrm{ft}$ were observed between these 12 historic observation wells and the nearby areal index wells. Most of these observed water-level differences may be due to the variability of the aquifer material over short vertical and horizontal distances or to differences in well construction. For figures 21-23, a water level was used for the waterlevel-change map for a selected period only if the measured water level was used for quarter-year-interval maps for both dates. For example, the Equus beds areal index wells were not used for figure 22 because none of the wells had water-level measurements before 2002 and, therefore, did not have water levels for the beginning date of this map. Also, except for well 886, the Equus beds historic observation wells near Equus beds areal index wells are not shown in figures 21-23 because their post-January 2005 water-level measurements were not used to construct quarter-year-interval water-level-change maps for periods ending after January 2005.

\section{Quarter-Year Intervals, 2003 to 2006}

The water-level changes since August 1940 for the period January 2003 to January 2006 (figs. 7-19) ranged from a decline of more than $36 \mathrm{ft}$ in a well about 1 mi northwest of well 886 near the center of the study area in July 2004 (fig. 13) to a rise of more than $2 \mathrm{ft}$ in April 2005 at a well near the northern edge of the study area (fig. 16). The shapes of the water-level-change contours since August 1940 for the period 


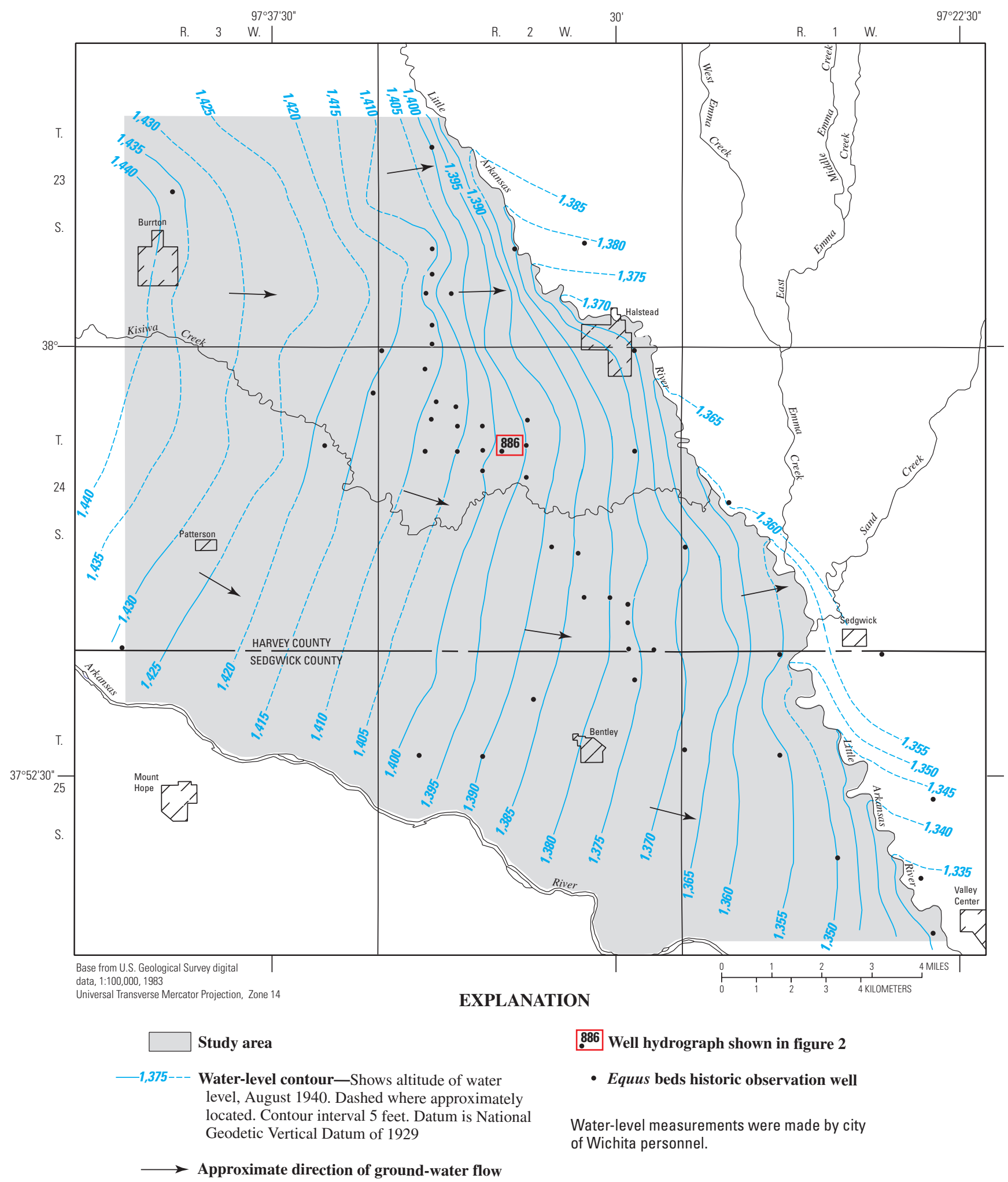

Figure 4. Water-level altitudes in Equus Beds aquifer in study area, August 1940 (modified from Stramel, 1956; Aucott and Myers, 1998). 


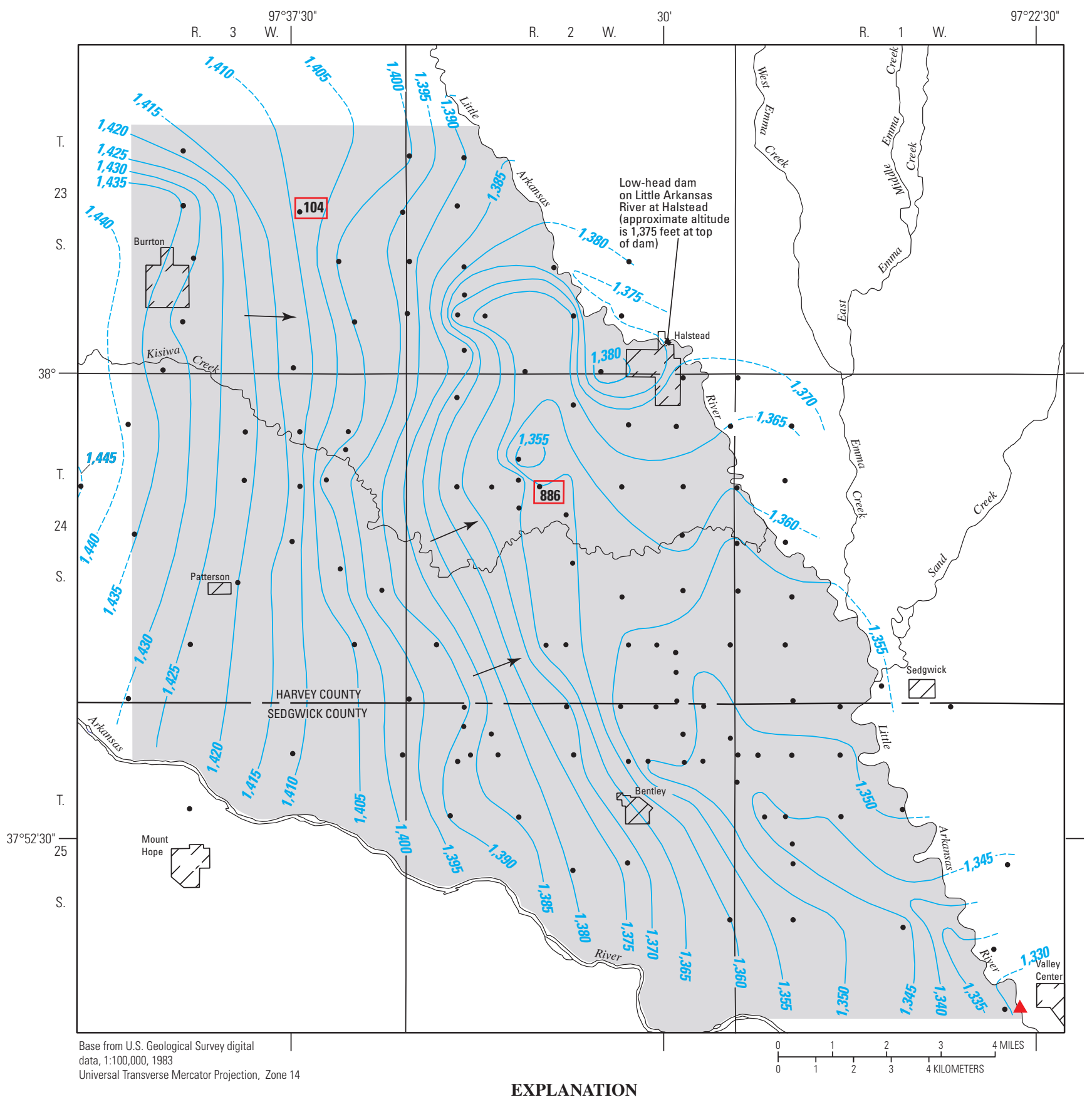

Study area

-1,375--- Water-level contour-Shows altitude of water level, October 1992. Dashed where approximately located. Contour interval 5 feet. Datum is National Geodetic Vertical Datum of 1929

\section{Approximate direction of ground-water flow}

$\Delta$ U.S. Geological Survey gaging station

.886 Well hydrograph shown in figure 2

- Equus beds historic observation well

Water-level measurements were made by city of Wichita personnel.

Figure 5. Water-level altitudes in Equus Beds aquifer in study area, October 1992 (modified from Hansen and Aucott, 2001). 


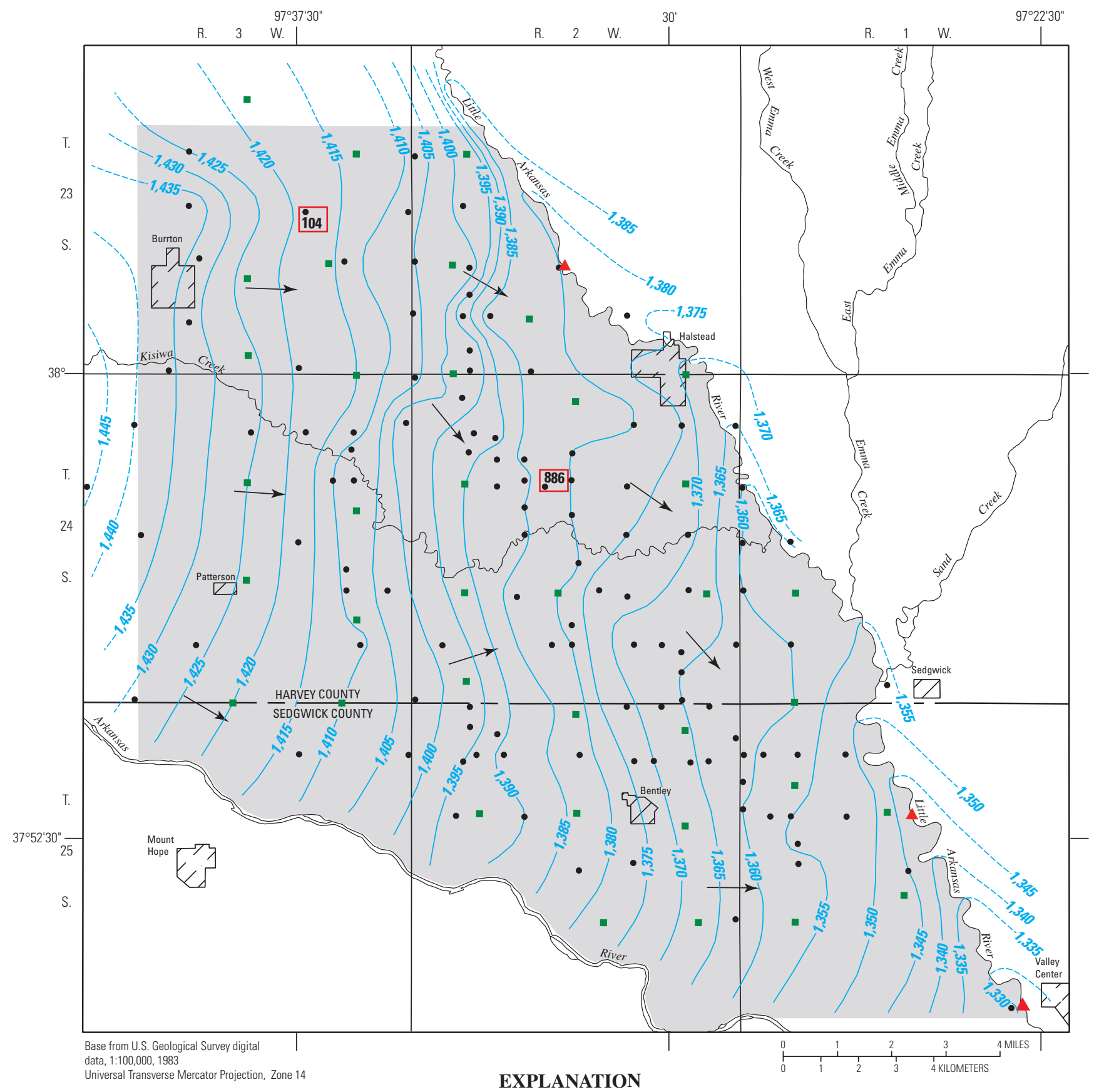

Study area

$\Delta$ U.S. Geological Survey gaging station

-1,405---- Water-level contour-Shows altitude of water level, January 2006. Dashed where approximately located. Contour interval 5 feet. Datum is North American Vertical Datum of 1988

Approximate direction of ground-water flow
886 Well hydrograph shown in figure 2

- Equus beds historic observation well

- Equus beds areal index well

Water-level measurements in wells were made by city of Wichita and Equus Beds Groundwater Management District No. 2 personnel. Water-level measurements at gaging stations were collected by U.S. Geological Survey.

Figure 6. Water-level altitudes in Equus Beds aquifer in study area, January 2006. 

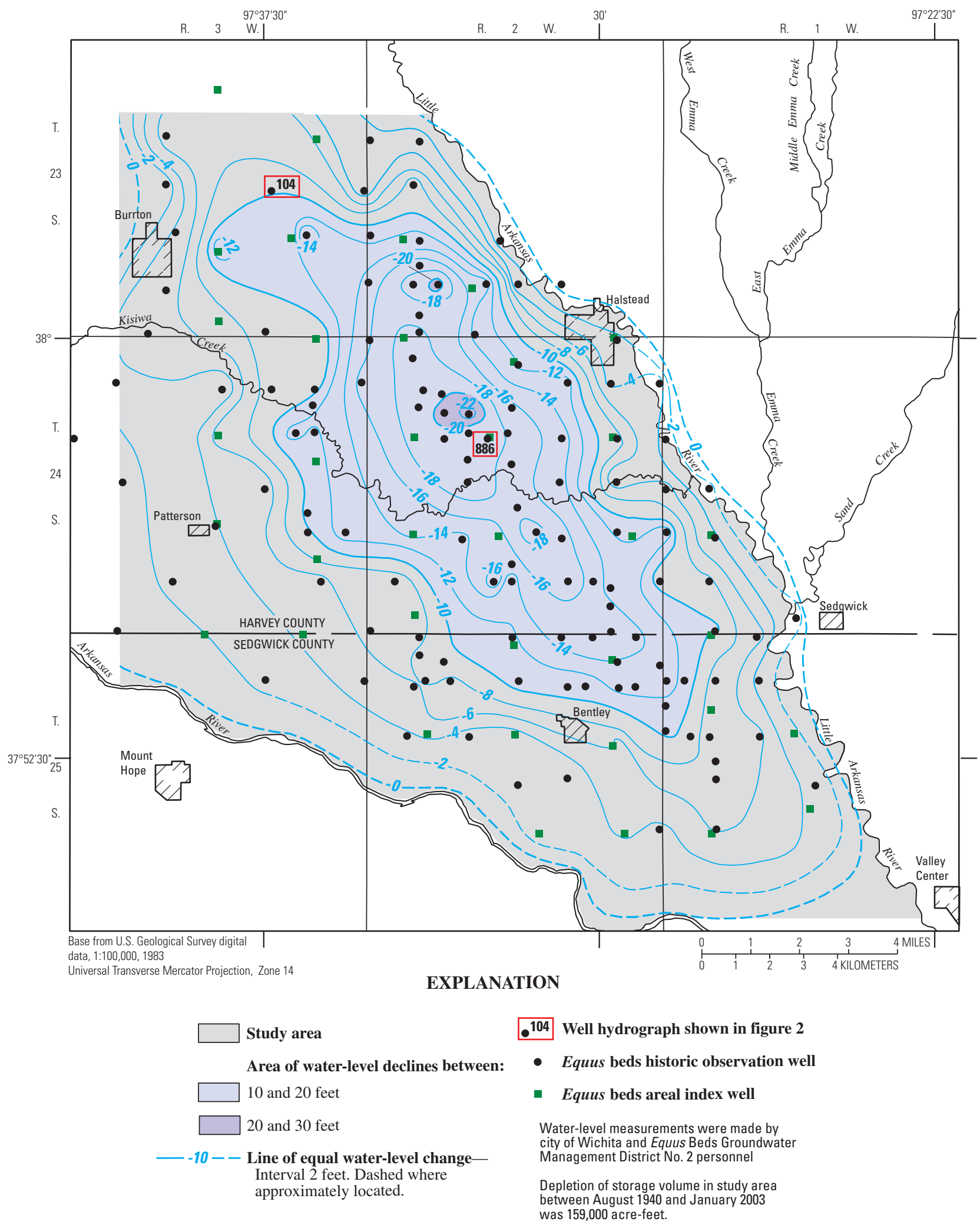

Figure 7. Water-level changes in Equus Beds aquifer in study area, August 1940-January 2003 (modified from Hansen and Aucott, 2004) 

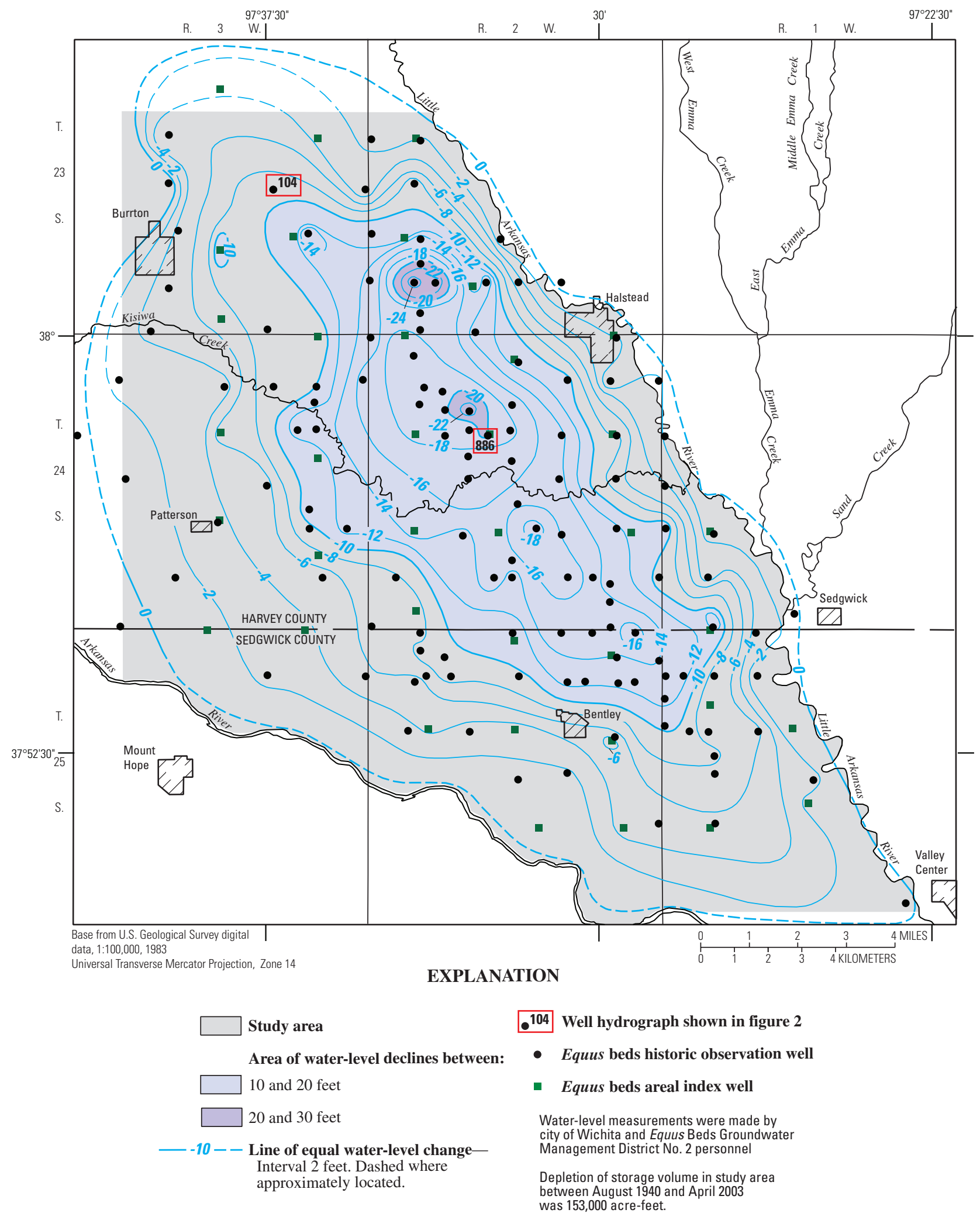

Figure 8. Water-level changes in Equus Beds aquifer in study area, August 1940-April 2003. 

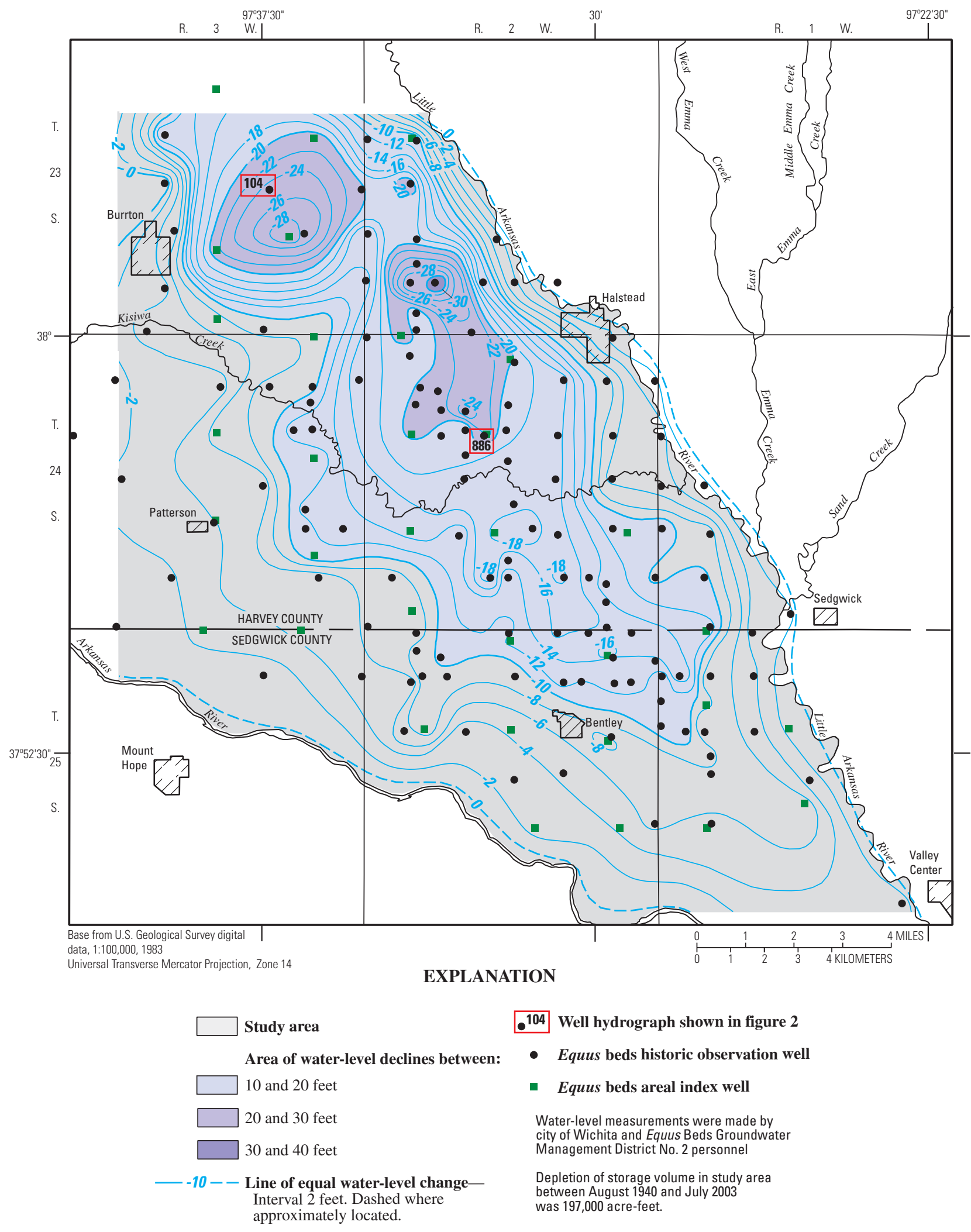

-104 Well hydrograph shown in figure 2

- Equus beds historic observation well

- Equus beds areal index well

Water-level measurements were made by city of Wichita and Equus Beds Groundwater Management District No. 2 personnel

Depletion of storage volume in study area between August 1940 and July 2003 was 197,000 acre-feet.

Figure 9. Water-level changes in Equus Beds aquifer in study area, August 1940-July 2003. 


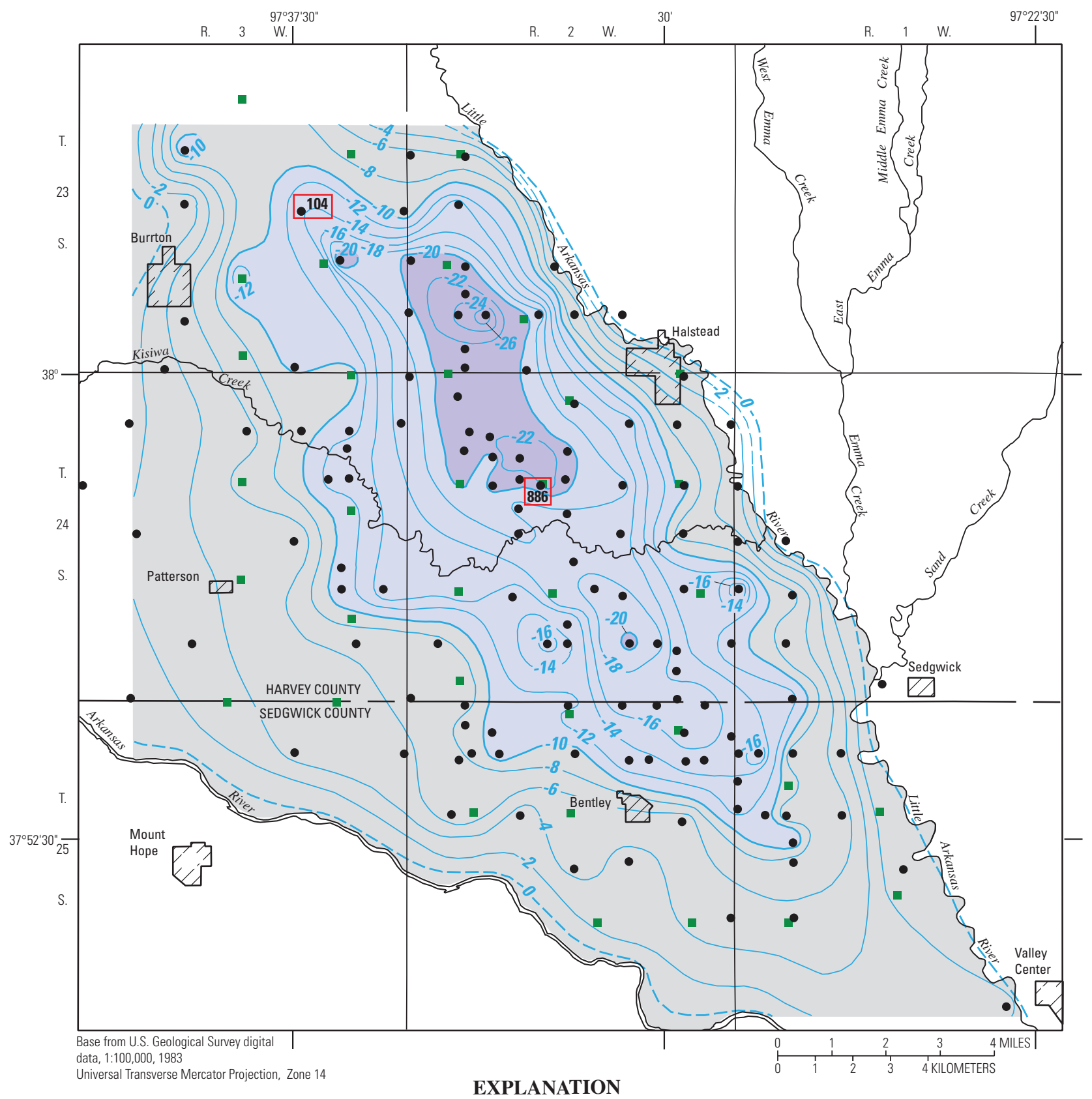

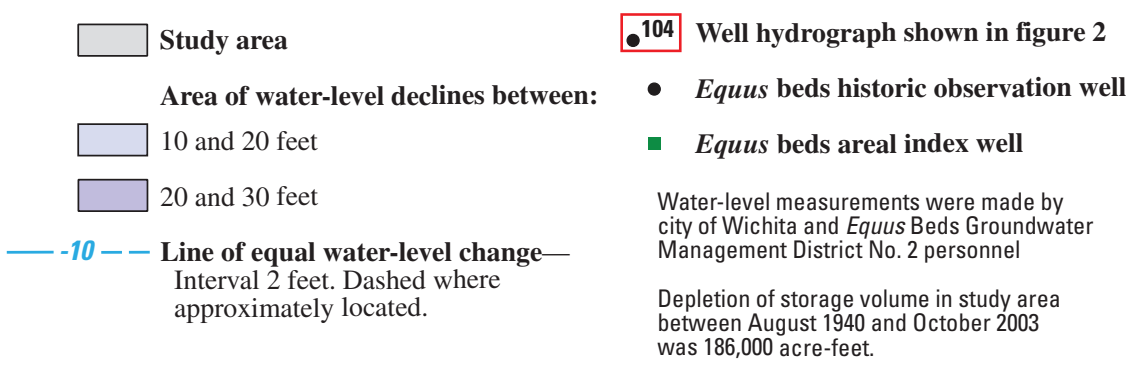

Figure 10. Water-level changes in Equus Beds aquifer in study area, August 1940-0ctober 2003. 


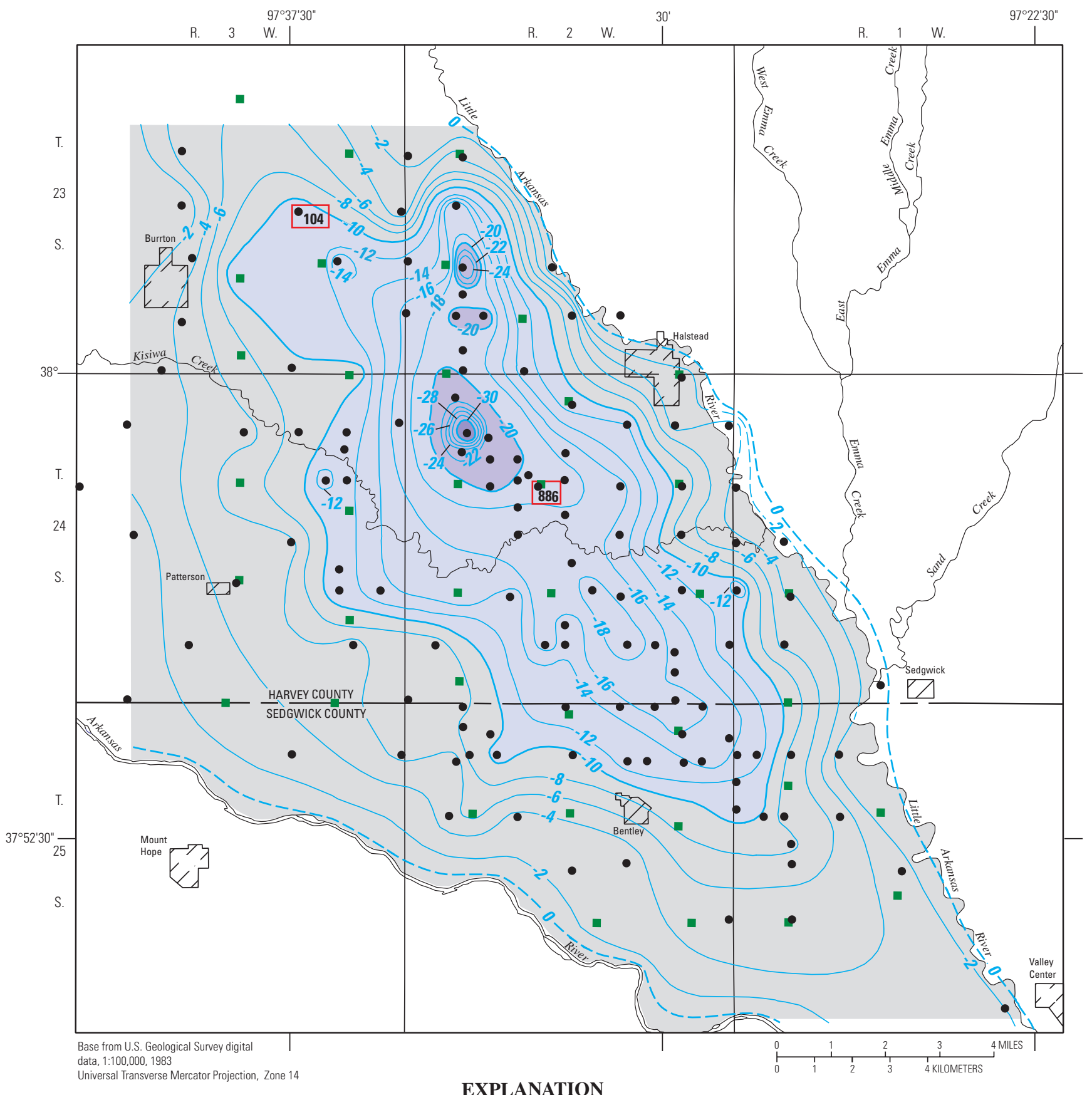

EXPLANATION

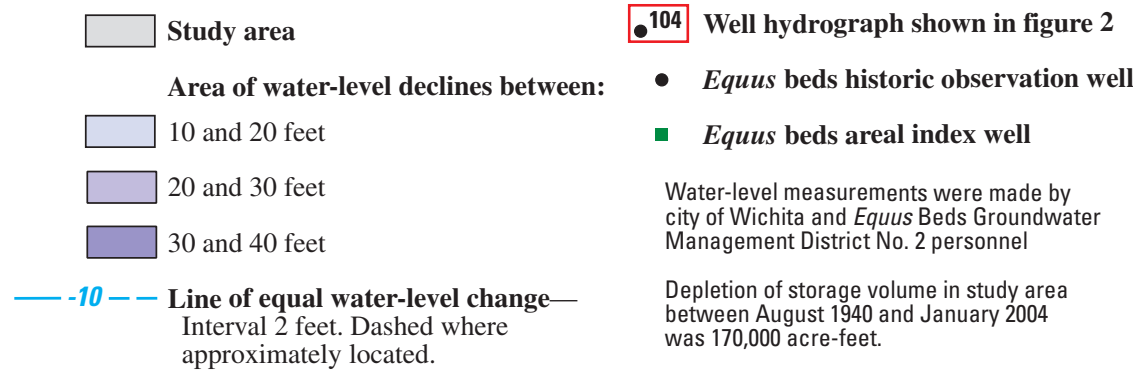

Figure 11. Water-level changes in Equus Beds aquifer in study area, August 1940-January 2004. 


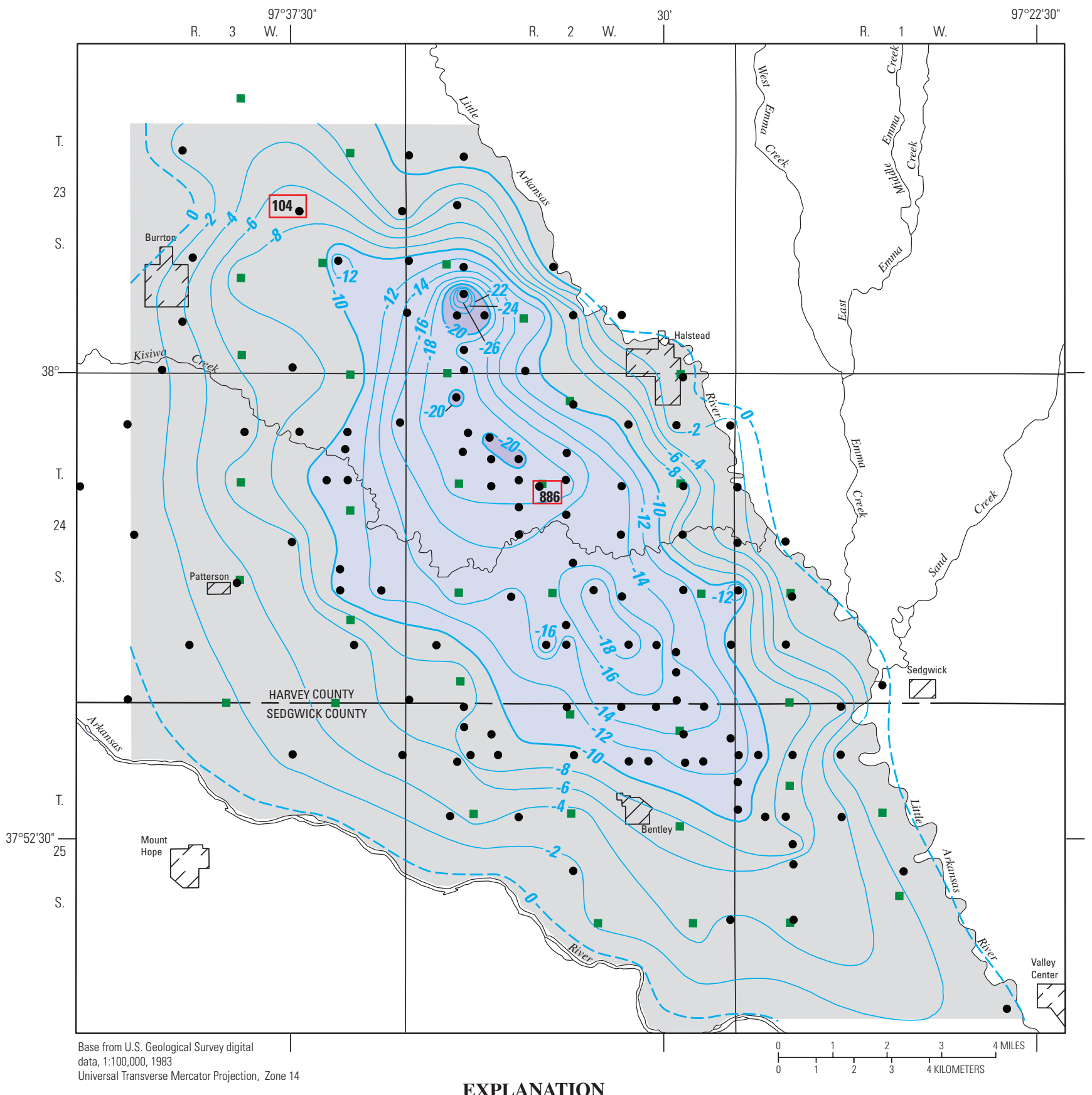

EXPLANATION

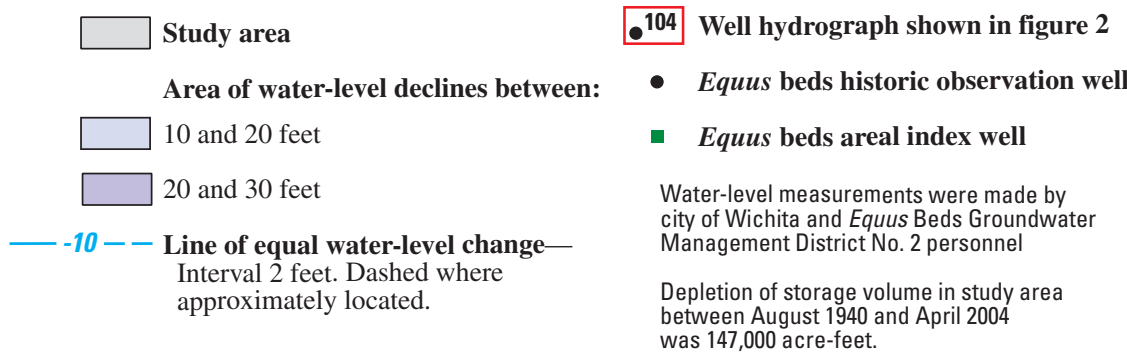

Figure 12. Water-level changes in Equus Beds aquifer in study area, August 1940-April 2004. 


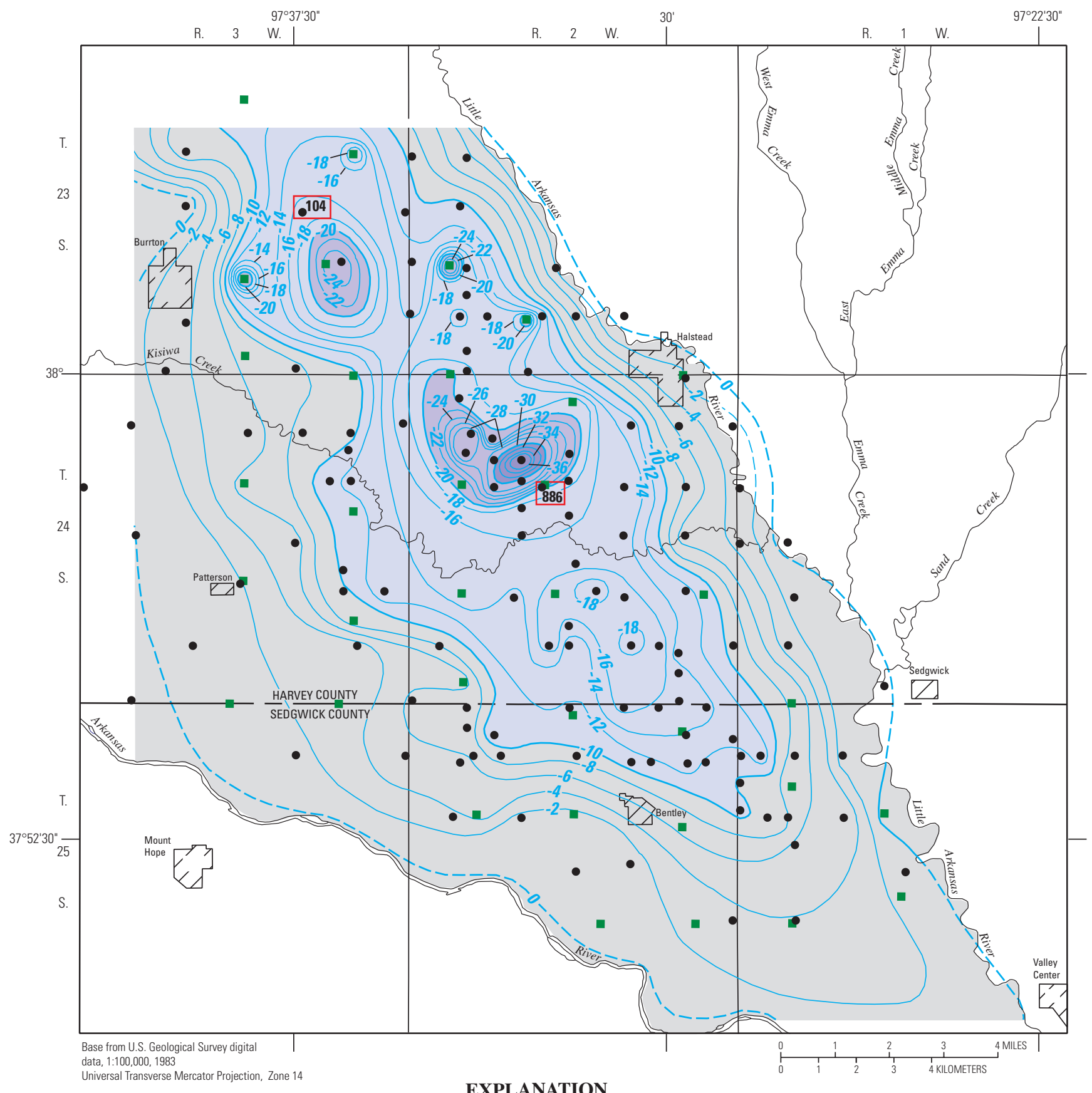

EXPLANATION

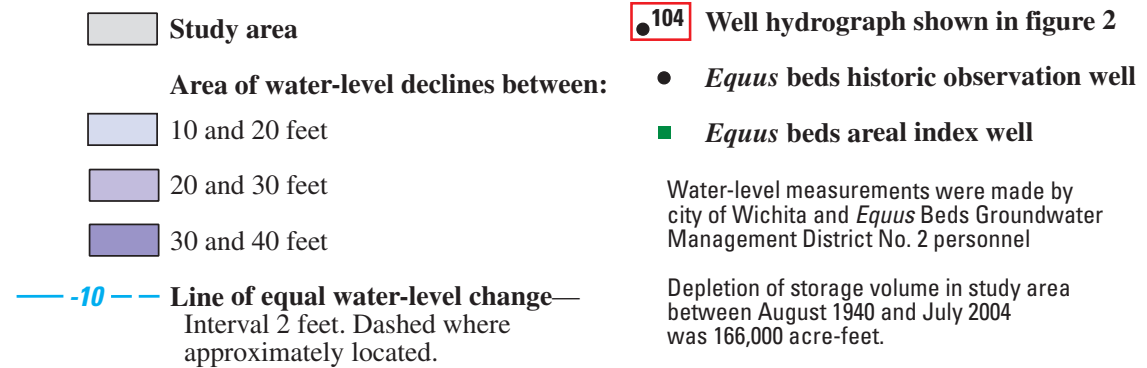

Figure 13. Water-level changes in Equus Beds aquifer in study area, August 1940-July 2004. 


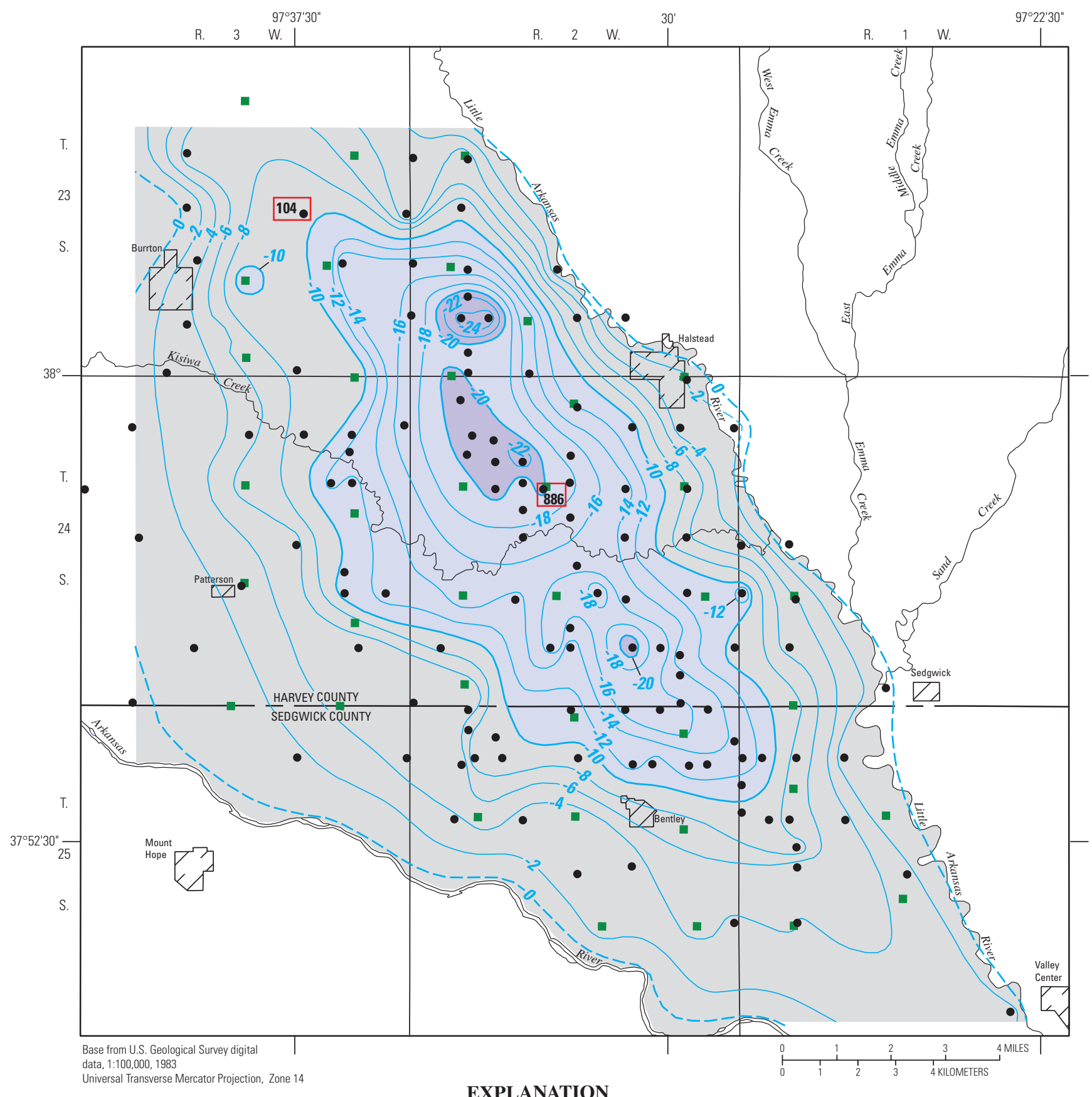

EXPLANATION

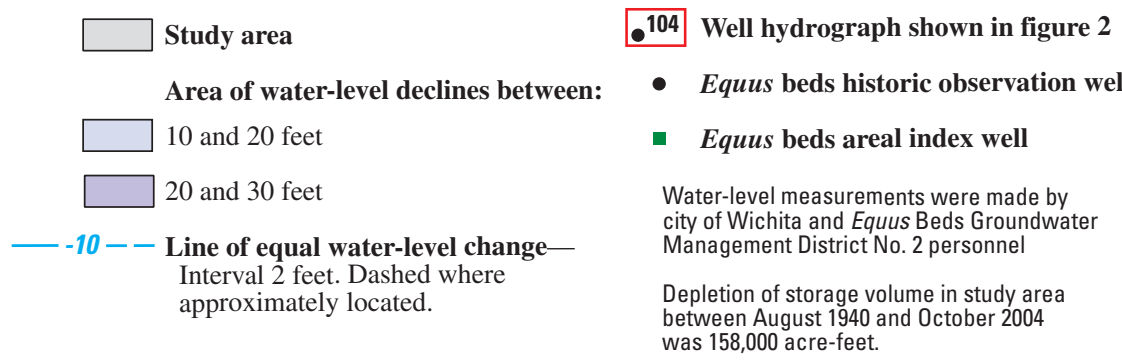

Figure 14. Water-level changes in Equus Beds aquifer in study area, August 1940-0ctober 2004. 


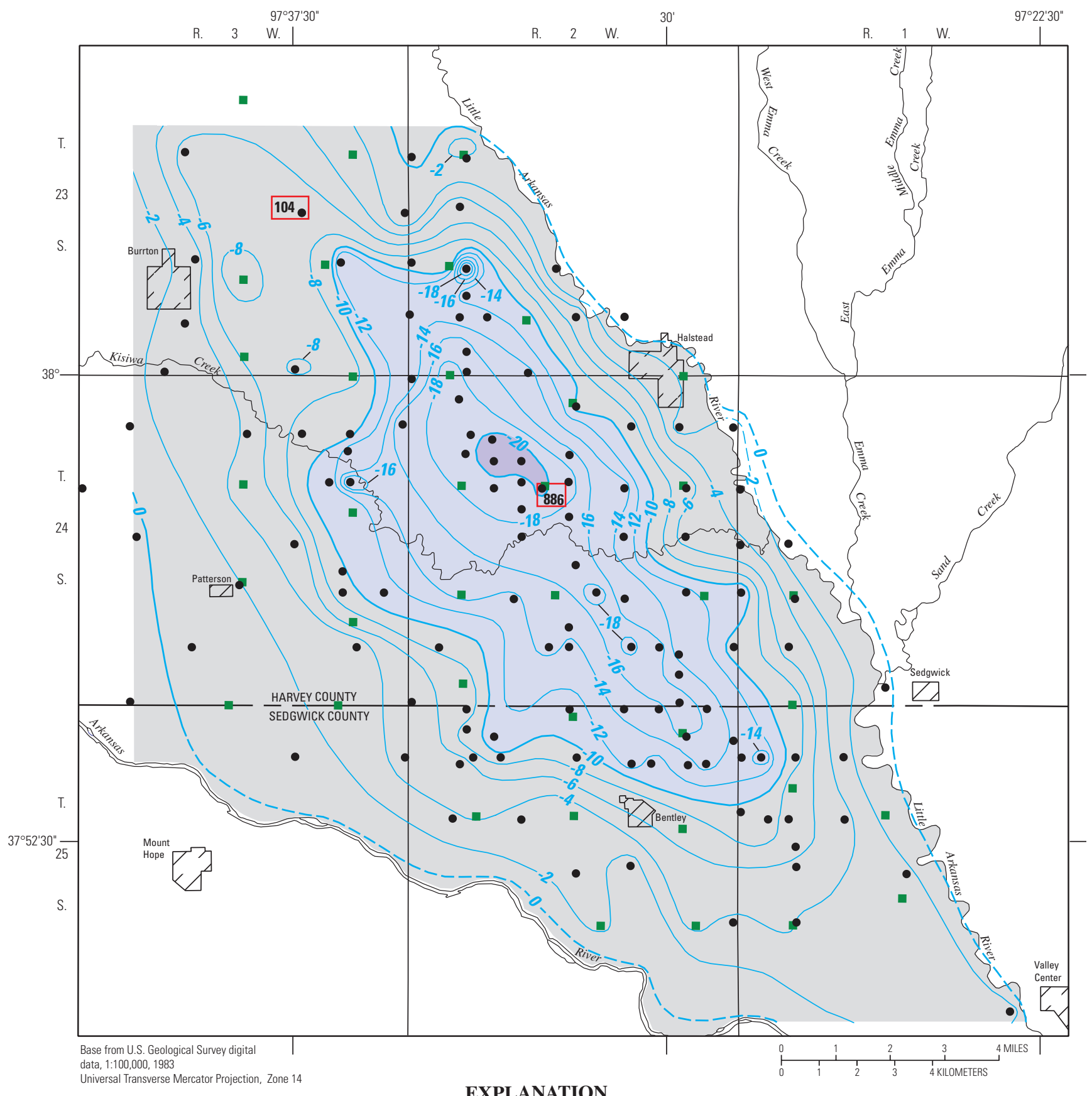

EXPLANATION

Study area

Area of water-level declines between:

10 and 20 feet

20 and 30 feet

- $-10--$ Line of equal water-level changeInterval 2 feet. Dashed where approximately located.
-104 Well hydrograph shown in figure 2

- Equus beds historic observation well

- Equus beds areal index well

Water-level measurements were made by city of Wichita and Equus Beds Groundwater Management District No. 2 personnel

Depletion of storage volume in study area between August 1940 and January 2005 was 143,000 acre-feet

Figure 15. Water-level changes in Equus Beds aquifer in study area, August 1940-January 2005. 


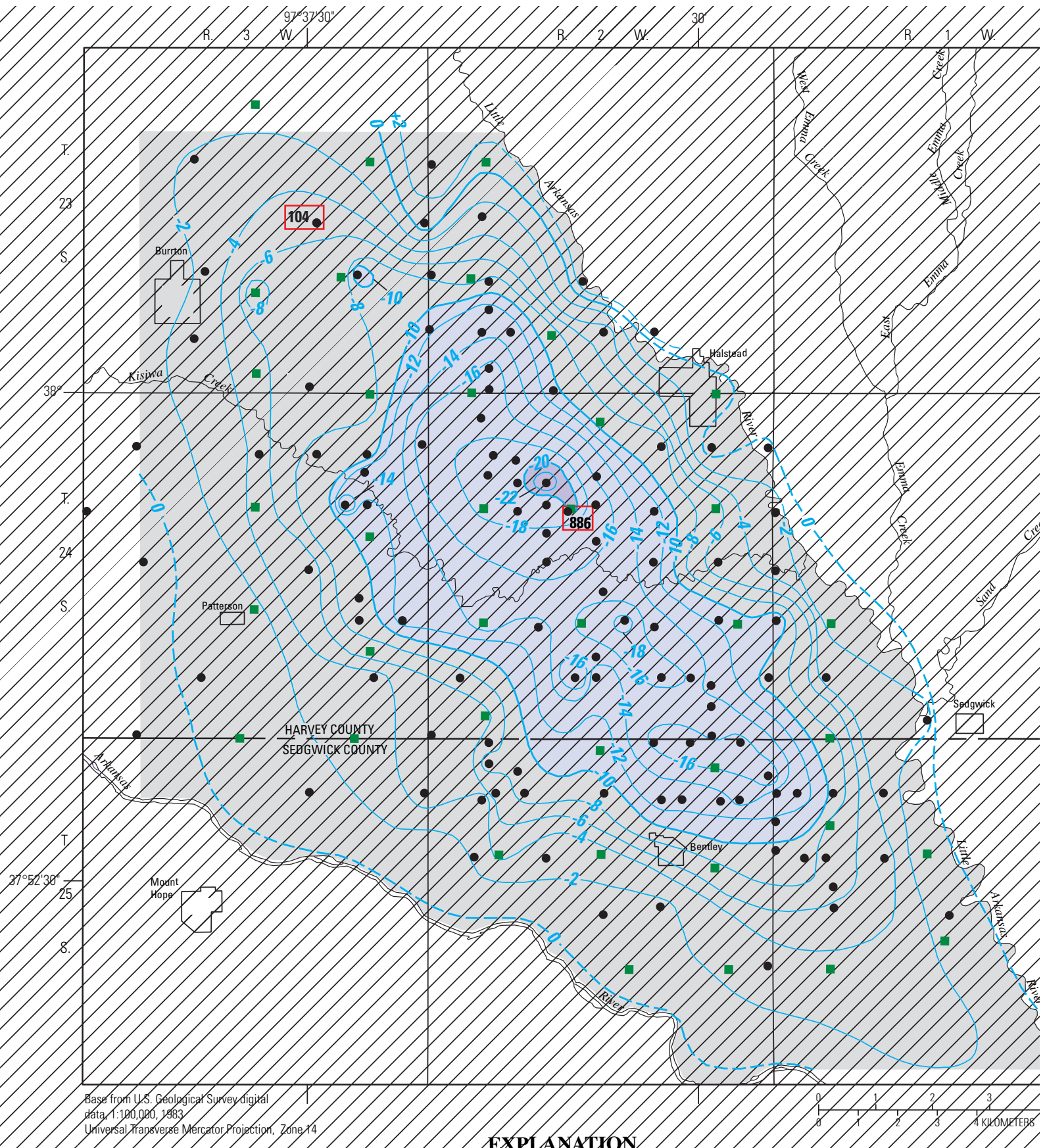

EXPLANATION

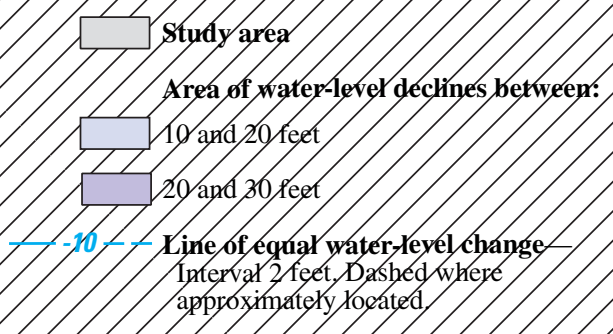

104 Well hydrograph shown in figure 2

- Equus beds historic observation well

- Equus beds areal index well

Water-level measurements were made by city of Wichita and Equus Beds Groundwater Management District No. 2 personnel

Depletion of storage volume in study area between August 1940 and April 2005 was 131,000 acre-feet.

Figure 16. Water-level changes in Equus Beds aquifer in study area, August 1940-April 2005. 


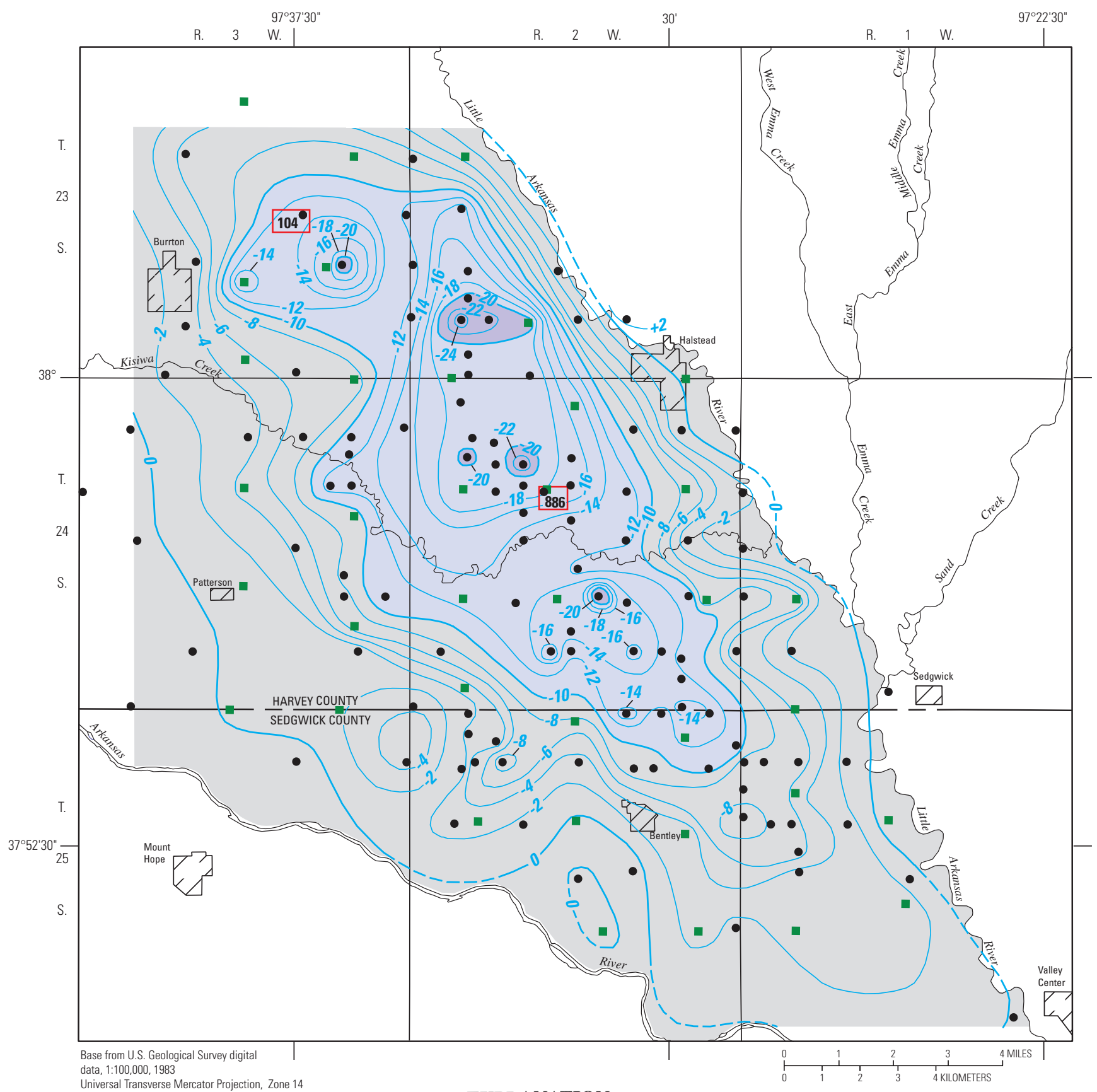

EXPLANATION

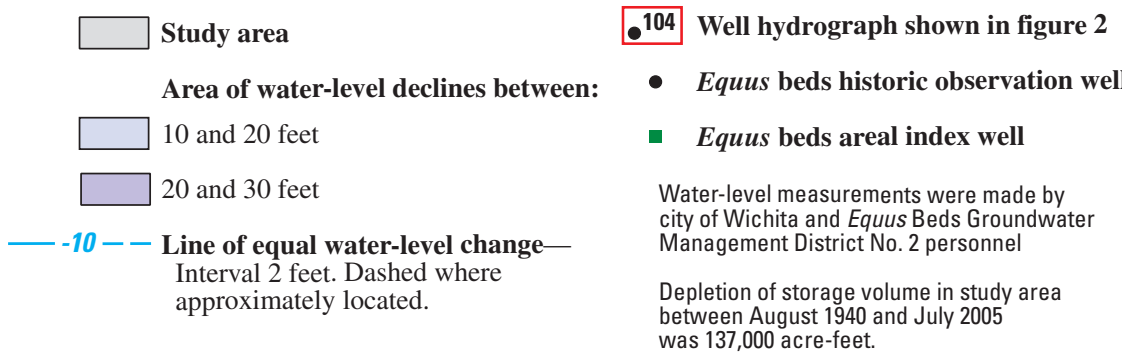

Figure 17. Water-level changes in Equus Beds aquifer in study area, August 1940-July 2005. 


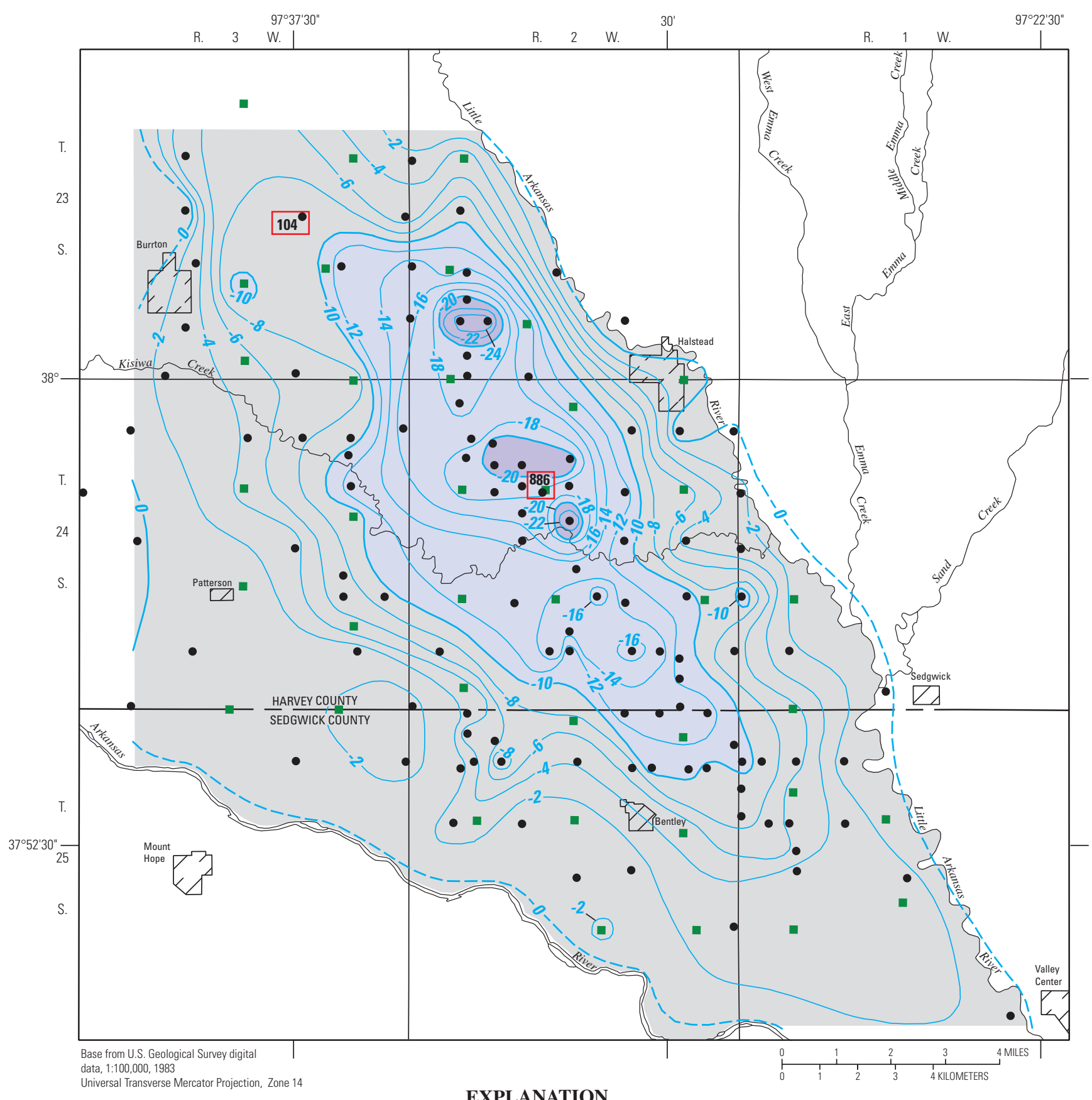

EXPLANATION

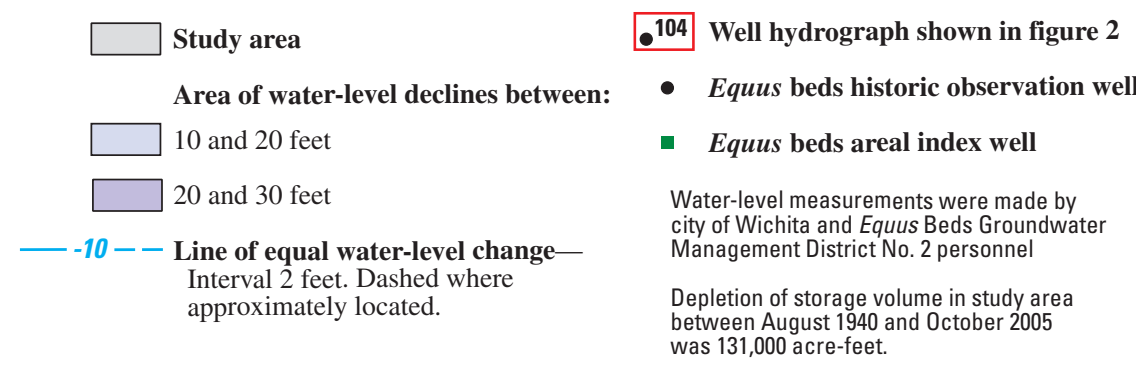

Figure 18. Water-level changes in Equus Beds aquifer in study area, August 1940-0ctober 2005. 


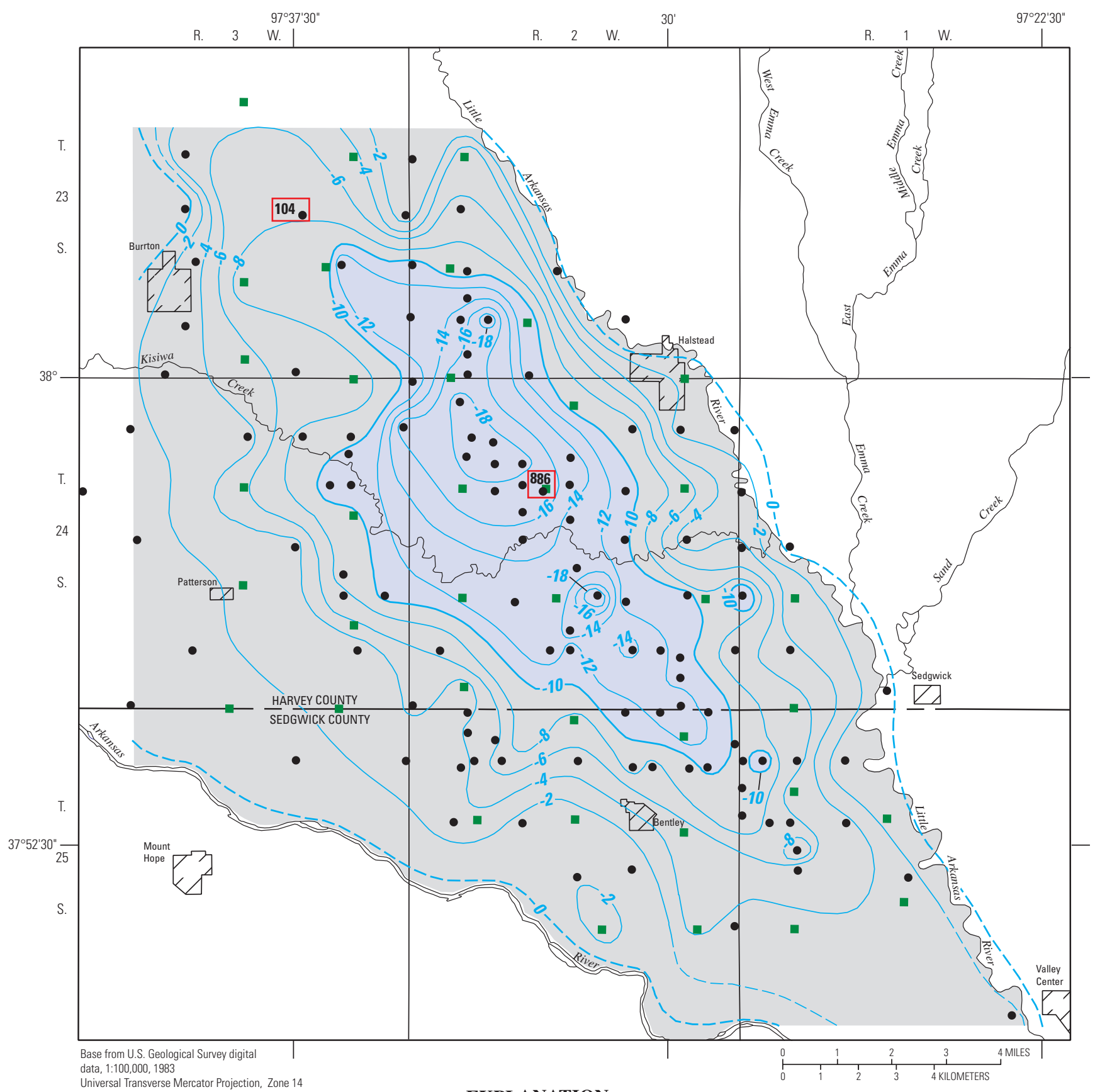

EXPLANATION

Study area

Area of water-level declines between:

10 and 20 feet

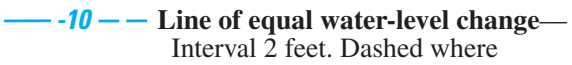
Interval 2 feet. Dashed where approximately located.
-104 Well hydrograph shown in figure 2

- Equus beds historic observation well

- Equus beds areal index well

Water-level measurements were made by city of Wichita and Equus Beds Groundwater Management District No. 2 personnel

Depletion of storage volume in study area between August 1940 and January 2006 was 127,000 acre-feet.

Figure 19. Water-level changes in Equus Beds aquifer in study area, August 1940-January 2006. 

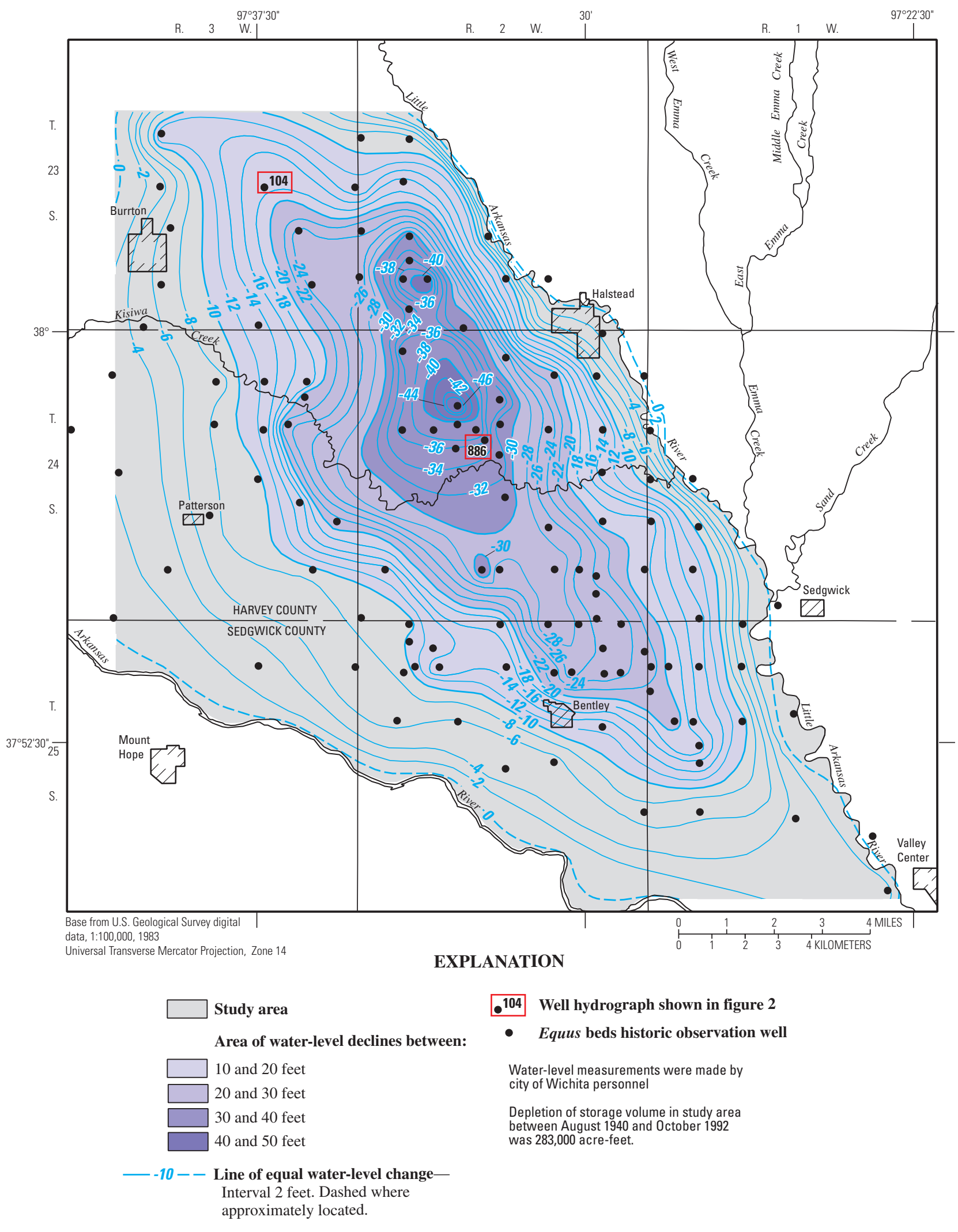

Figure 20. Water-level changes in Equus Beds aquifer in study area, August 1940-0ctober 1992 (modified from Aucott and Hansen, 2001). 


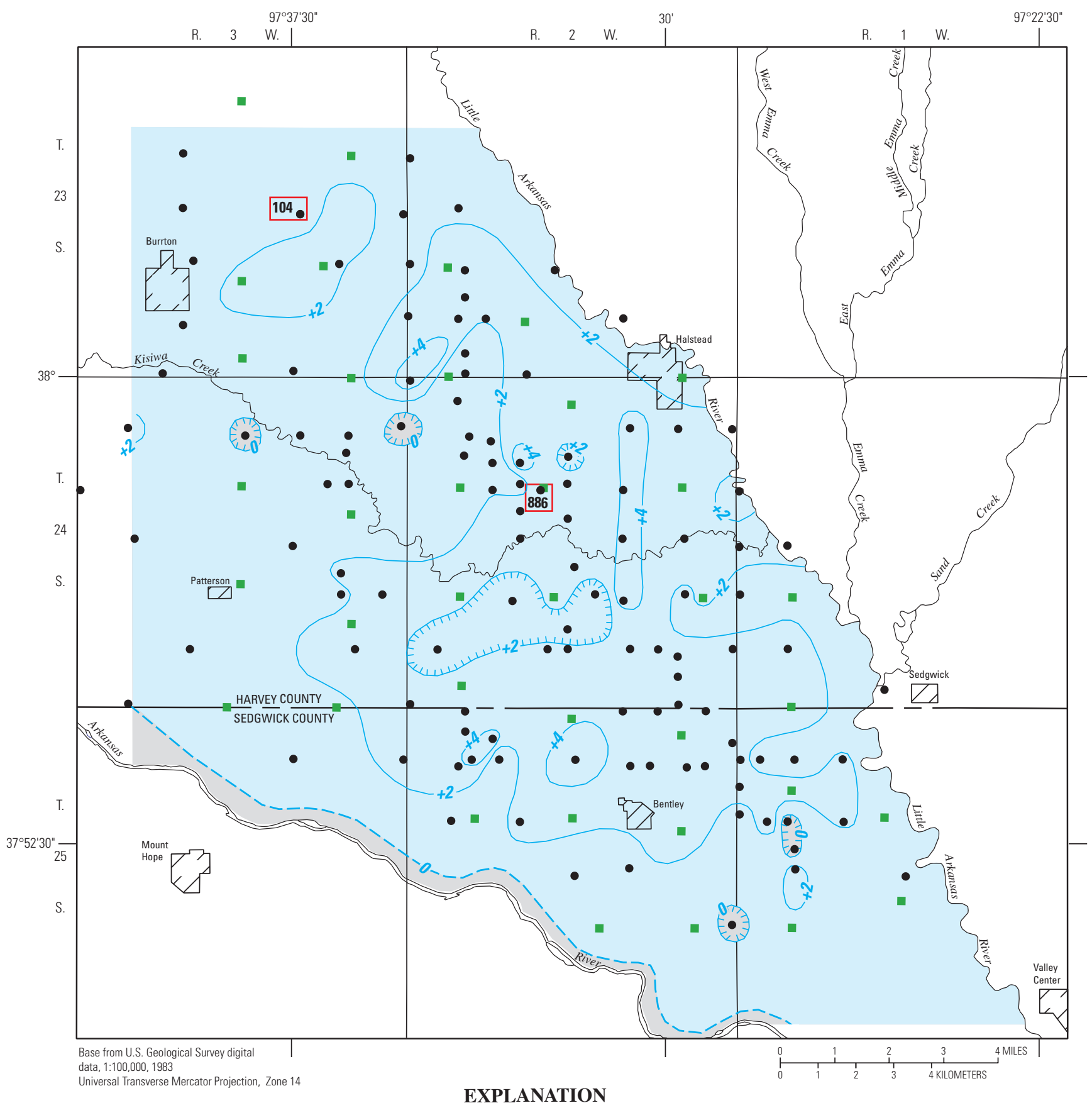

Study area

Area of water-level recovery between:

0 and +10 feet

$-+2--$ Line of equal water-level change - Interval

2 feet. Dashed where approximately located.

Hachures indicate closed areas where the water-

level change is a smaller rise or a larger decline

than the surrounding area
-104 Well hydrograph shown in figure 2

- Equus beds historic observation well

- Equus beds areal index well

Water-level measurements were made by city of Wichita and Equus Beds Groundwater Management District No. 2 personnel

Recovery of storage volume in study area between January 2003 and January 2006 was 32,000 acre-feet.

Figure 21. Water-level changes in Equus Beds aquifer in study area, January 2003-January 2006. 


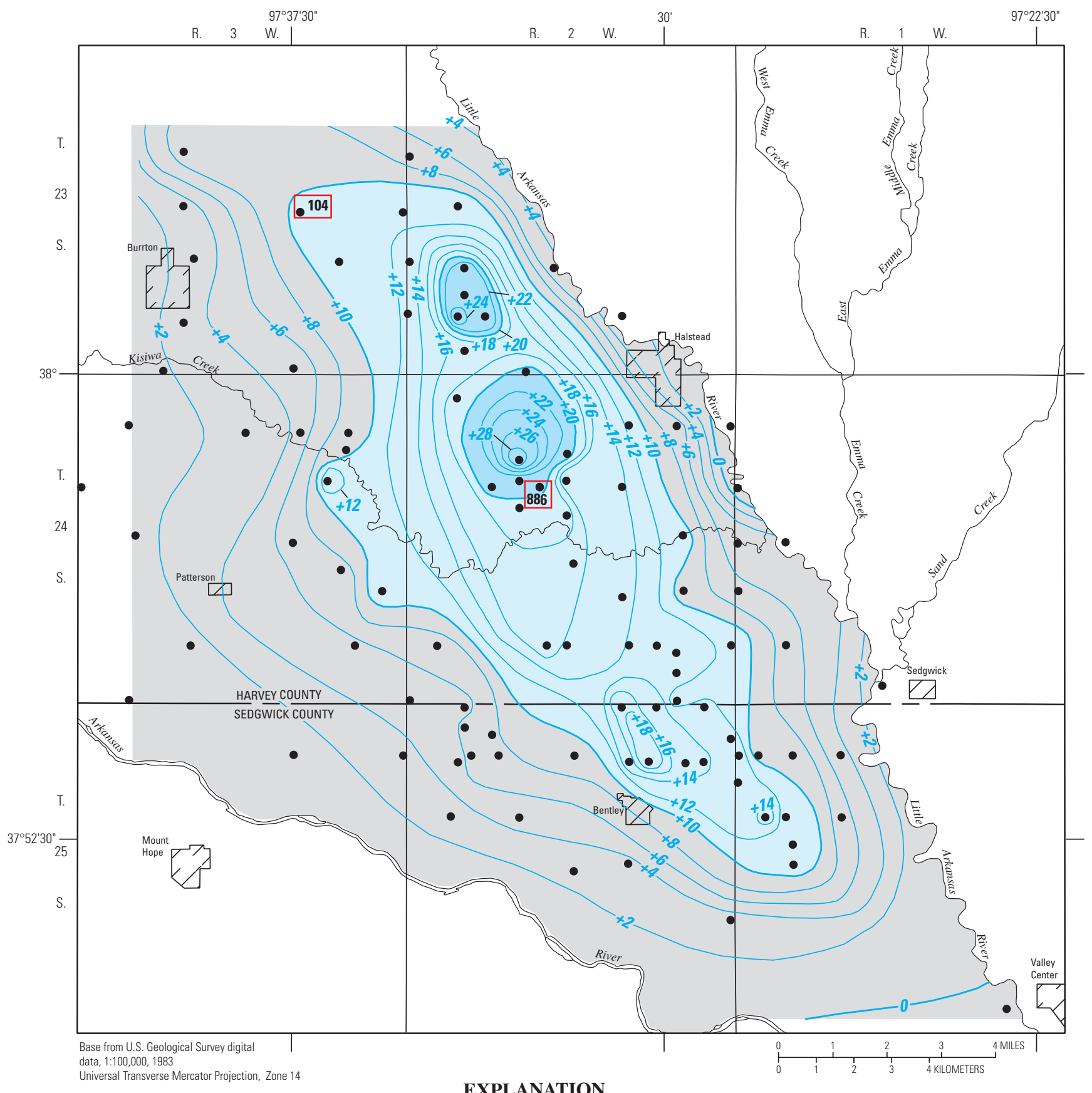

EXPLANATION

Study area

Area of water-level recovery between:

+10 and +20 feet

+20 and +30 feet

$-+10-$ Line of equal water-level changeInterval 2 feet.
104 Well hydrograph shown in figure 2

- Equus beds historic observation well

Water-level measurements were made by city of Wichita personnel

Recovery of storage volume in study area between October 1992 and January 2006 was 156,000 acre-feet.

Figure 22. Water-level changes in Equus Beds aquifer in study area, October 1992-January 2006. 


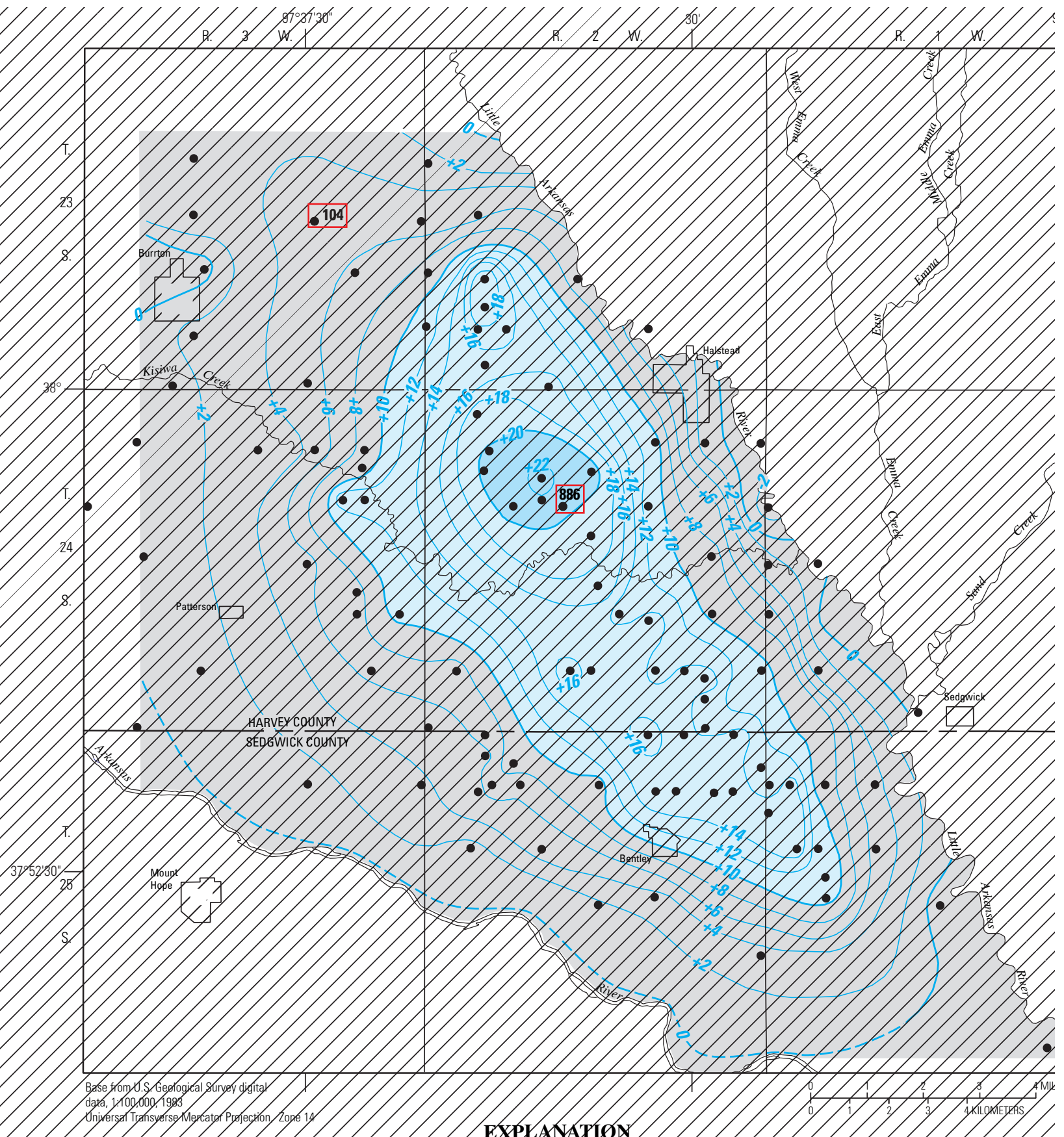

EXPLANATION

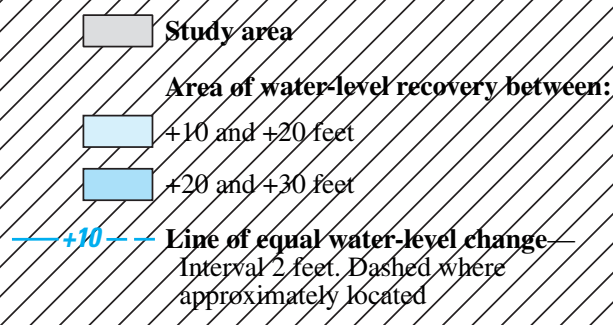

-104 Well hydrograph shown in figure 2

- Equus beds historic observation well

Water-level measurements were made by city of Wichita personnel

Recovery of storage volume in study area between January 1993 and January 2006 was 128,000 acre-feet.

Figure 23. Water-level changes in Equus Beds aquifer in study area, January 1993-January 2006. 
January 2003 to January 2006 (figs. 7-19) are similar to those published for recent years (Aucott and Myers, 1998; Aucott and others, 1998; Hansen and Aucott, 2001, 2004). Comparisons of figures 7-19 show the annual cycle of water-level declines and rises that generally occur in the study area. Typically, the largest water-level declines occur during the summer or fall when agricultural irrigation and city pumpage are greatest. During the period January 2003 to January 2006, this is shown most distinctly by the expansion of areas with waterlevel declines of $20 \mathrm{ft}$ or more on the July and October maps of water-level changes since August 1940 and the occurrence of areas with declines of $30 \mathrm{ft}$ or more on the July 2003 and July 2004 maps (figs. 9, 10, 13, 14, 17, and 18). As vegetation and human water use decrease following the summer months, so does agricultural irrigation and city pumpage, resulting in water-level rises that can continue into the following spring. The maps of water-level changes since August 1940 for the period January 2003 to January 2006 show these water-level rises most obviously as the decrease in the size of the areas with declines of $20 \mathrm{ft}$ or more in the January and April maps and their complete disappearance by January 2006 (figs. 7, $8,11,12,15,16$, and 19). The complete disappearance of declines of $20 \mathrm{ft}$ or more was not seen in other maps of waterlevel changes between August 1940 and quarter-year intervals from January 1997 to the present (2006) (Aucott and others, 1998; Hansen and Aucott, 2001, 2004; and figs. 7-19). This would seem to confirm that the post-October 1992 period of water-level recovery was continuing in January 2006.

\section{Cumulative Change, 2003 to 2006}

The water-level-change map for the period January 2003 to January 2006 shows almost all wells in the study area experienced small cumulative water-level rises since the last report on water levels in the areas by Hansen and Aucott (2004) (fig. 21). Seasonal water-level changes for most wells in the study area during January 2003 to January 2006 continued to be larger than the cumulative water-level change for the same period (for example, see hydrographs of observation wells 104 and 886 in fig. 2C). Cumulative water-level changes from January 2003 to January 2006 ranged from declines of less than $2 \mathrm{ft}$ in several small isolated areas in the western and southeastern parts of the study area (enclosed by hachured lines of zero water-level change in figure 21) to rises of 4 or more $\mathrm{ft}$ in several places near the center of the study area (fig. 21). The cumulative water-level changes from January 2003 to January 2006 commonly were rises of more than $2 \mathrm{ft}$ in and near the center of the study area and generally were rises of less than $2 \mathrm{ft}$ in the rest of the study area (fig. 21).

\section{Cumulative Change Since Period of Maximum Decline}

As pointed out previously by Hansen and Aucott (2001 and 2004), the maximum recorded decline in the study area occurred in October 1992 (fig. 20); therefore, a map for the period October 1992 to January 2006 was constructed to illustrate the magnitude of cumulative water-level changes since the period of maximum decline (fig. 22). The cumulative water-level changes from October 1992 to January 2006 ranged from a decline of less than $2 \mathrm{ft}$ in T. $24 \mathrm{~S}$., R. $1 \mathrm{~W}$. near the Little Arkansas River and in the extreme southeastern part of the study area to a rise of more than $28 \mathrm{ft}$ in a well about $0.5 \mathrm{mi}$ mile northwest of well 886 near the center of the study area (fig. 22). Almost all the wells in the study area had cumulative water-level rises from October 1992 to January 2006 (fig. 22). For this period, a single large area of cumulative water-level rises of $10 \mathrm{ft}$ or more occurred throughout most of the center of the study area, and two areas with rises of $20 \mathrm{ft}$ or more occurred in the northern and center parts of the study area (fig. 22). The water-level-change map for the period January 1993 to January 2006 (fig. 23), which can be used for readers who prefer year-to-year comparisons, shows a similar but slightly more subdued pattern of water-level rises than the October 1992 to January 2006 map.

Changes in city and irrigation pumpage and in precipitation should be expected to be the major factors affecting recharge and thus changes in aquifer water levels and storage volume. The area with water-level rises of $10 \mathrm{ft}$ or more between October 1992 and January 2006 was almost entirely within the center of the study area where all city pumpage from the Equus Beds aquifer occurred (fig. 22). As a result, it would be reasonable to conclude that the reduction in city pumpage from the aquifer between October 1992 and January 2006 (from about 36,900 acre-ft in 1992 to about 23,600 acre$\mathrm{ft}$ in 2005) (fig. 2B) had a greater effect on increasing recharge and thus water-level rises in the aquifer than did increased precipitation, which was probably roughly evenly distributed throughout the study area during the period. An important factor in the decreased city pumpage from the aquifer was increased use of Cheney Reservoir by the city of Wichita as a water-supply source; as a result, city pumpage from the Equus Beds aquifer during 1992-2002 was cut almost in half (from about 36,900 to 18,600 acre-ft) and decreased from about 60 to about 30 percent of Wichita's water usage. City pumpage from the aquifer stabilized at about 40 percent of Wichita's usage during 2003-05 and was similar to quantities pumped in the late 1940 s (fig. $2 B$ ). Generally greater-than-average precipitation in the study area between October 1992 and January 2006 (averaging about 1.84 in. greater during 1992-2005 than the long-term (1940-2005) annual average precipitation of 31.35 in.) (fig. $2 A$ ) likely contributed to the increase in recharge and the water-level rises of less than $10 \mathrm{ft}$ throughout the study area (fig. 22). For the period October 1992 to January 2006, irrigation pumpage actually increased (from about 20,100 acre-ft in 1992 to about 29,200 acre-ft in 2005) (fig. $2 B$ ), so irrigation pumpage did not increase recharge or contribute to the observed water-level rises overall during that period. Because irrigation pumpage can vary considerably from year to year due to climatic variations, reduced irrigation pumpage could contribute to rises in particular years even 
though it did not contribute to the overall rise between October 1992 and January 2006. A more definitive accounting of the causes of these water-level rises would require a ground-water flow model.

\section{Storage-Volume Changes}

Changes in storage volume are defined for the purposes of this report as the change in saturated aquifer volume multiplied by the specific yield of the aquifer. A specific yield of 0.2 has been used to compute the changes in storage volume in the Equus Beds aquifer since Stramel (1956) first computed storage volume for the aquifer. The use of a specific yield of 0.2 was retained in this report because, as reported by Hansen and Aucott (2001), it is within the range of most estimates of specific yield and because there is no general agreement on an average value of specific yield for the Equus Beds aquifer in the study area.

The changes in storage volume since August 1940 for the selected time periods shown in table 1 were computed using computer-generated Thiessen polygons (Thiessen, 1911) that were based on the measured water-level changes at wells and the manually drawn lines of equal water-level change (figs. 7-20). Theissen polygons apportion the water-level change at each well and at points representing the lines of equal water-level change to the area around the wells and points. The volume of storage change was computed by summing the area of each Theissen polygon multiplied by the actual water-level change value associated with the Theissen polygon and then by the specific yield. To determine the storage-volume change since August 1940 in the study area and the central part of the study area (table 1), the computation was done for the Theissen polygons within the whole study area and for those within the central part of the study area, respectively.

Changes in storage volume since October 1992, as shown in table 1, were calculated as the difference between changes in storage volumes for August 1940 to the beginning of the selected time period and for August 1940 to the end of the selected time period. For example, the change in storage volume for January 2003 to January 2006, as shown in table 1, was calculated as the difference between the change in storage volume for August 1940 to January 2006 and for August 1940 to January 2003. The changes in storage volume since predevelopment (August 1940), since the period of maximum decline (October 1992), and since the beginning of the current reporting period (January 2003) are shown in table 1 for both the study area and the central part of the study area. Also included in table 1 for both areas are the changes in storage volume since October 1992 as a percentage of the storage volume lost between August 1940 and October 1992. The changes in storage volume for the study area since August 1940 are shown graphically in figure $2 C$.
Following the maximum loss of storage that occurred from August 1940 to October 1992 in the study area (Hansen and Aucott, 2001), storage volume recovered until early 2000 and then tended to decrease until the end of the last reporting period in January 2003 (Hansen and Aucott, 2004) (table 1). In the current study period, which began in January 2003, this tendency for aquifer storage volume to decrease continued until July 2003 in the study area and October 2003 in the central part of the study area when storage-volume changes since August 1940 were -197,000 and -92,300 acre-ft, respectively (table 1 and fig. $2 C$ ). This decrease in storage volume during 2000-2003 occurred despite substantial decreases in annual city pumpage from the aquifer during 2000-2003 (fig. 2B).

Since late 2003, storage volumes in both the study area and the central part of the study area tended to increase until January 2006 (table 1, fig. 2C). In January 2006, the smallest storage-volume depletions since August 1940 for the period January 2003 to January 2006 occurred in both areas (-127,000 and -68,900 acre-ft, respectively) (table 1 and fig. $2 C$ ). Water levels and storage volumes in January 2006 were similar to those seen in the late 1970s (fig. 2C).

The storage-volume change in the study area for the period October 1992 to January 2006 represents a recovery of about 156,000 acre-ft or about 55 percent of storage previously lost between August 1940 and October 1992 in the study area (table 1). This recovery in the study area approaches postOctober 1992 recoveries previously seen in early 2000

(table 1). The storage-volume change in the central part of the study area for October 1992 to January 2006 represents about 90,100 acre-ft or about a 57-percent recovery of storage lost between August 1940 and October 1992 in this part of the study area (table 1). This is the largest post-October 1992 recovery to date in the central part of the study area, even surpassing the recovery seen in January 2000 (table 1).

\section{Effects of Artificial Recharge}

Discussions about using artificial recharge to enhance the water supply in the Equus Beds aquifer have been occurring since the 1950s (for example, Stramel, 1956; Albert and Stramel, 1966). During 1995-2002, the Equus Beds Ground-Water Recharge Demonstration Project investigated the potential for artificial recharge to meet future water-supply needs and to protect the Equus Beds aquifer from the intrusion of saltwater from natural and human-related sources to the west (Ziegler and others, 1999). The recharge demonstration project was constructed through a cooperative effort among the city of Wichita and Federal, State, and local agencies. As a part of this project, two artificial recharge demonstration sites were located in the central part of the study area near Halstead and Sedgwick (fig. 1). Artificial recharge operations occurred during May 1997-June 2002 at the Halstead site and during April 1998-November 2000 at the Sedgwick site (Hansen and Aucott, 2004). The effects of the amount of artificial recharge 


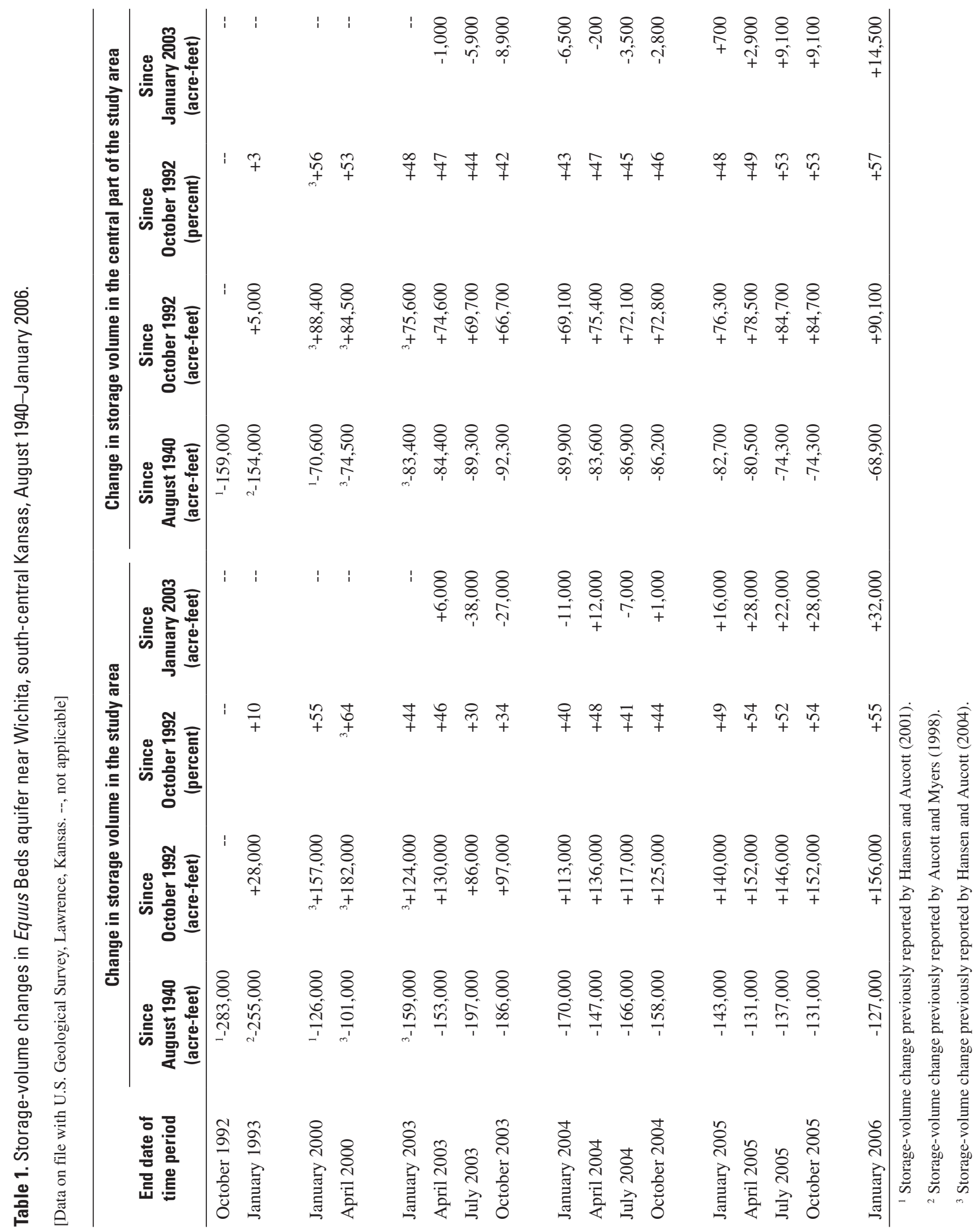


during this period, which was equivalent to less than 3 percent of the water pumped by the city from the study area during 1997-2002, were masked by the generally larger decreases in city pumpage in the central part of the study area that occurred during the same period (Hansen and Aucott, 2004). No artificial recharge occurred in the study area during the current reporting period of January 2003 to January 2006. The city of Wichita plans to resume artificial recharge of the Equus Beds aquifer on a much larger scale after construction of Phase I of the Equus Beds Aquifer Storage and Recovery Project (scheduled for completion in September 2006) (Gerald T. Blain, city of Wichita, oral commun., March 16, 2006). Artificial recharge will be allowed to occur only during periods when flows in the Little Arkansas River are greater than the minimum levels set by the State of Kansas (Approval of Application and Permit to Proceed Application File Nos. 45569 through 45575, Kansas Department of Agriculture, Division of Water Resources, Topeka, Kansas, 2005). The artificial recharge is expected to cause water levels to rise areally, but especially where water is locally added, all other factors such as precipitation, city pumpage, and agricultural irrigation being equal.

\section{Summary}

The Equus Beds aquifer in southwestern Harvey County and northwestern Sedgwick County was developed to supply water to Wichita residents and for irrigation in south-central Kansas. Ground-water pumpage for city and agricultural use from the aquifer caused water levels to decline in a large part of the study area. In 1965, the city of Wichita began using water from Cheney Reservoir in addition to water from the Equus Beds aquifer and thus reduced the amount of water that would have been pumped from the Equus Beds aquifer. Irrigation pumpage in the area increased substantially during the 1970s and 1980s and accelerated water-level declines. Most of the water-level declines can be attributed to ground-water pumping; however, climatic conditions (and thus variations in recharge to the Equus Beds aquifer) also have affected groundwater levels. Since 1995, the city has been investigating the use of artificial recharge in the study area to meet future watersupply needs and to protect the aquifer from the intrusion of saltwater from natural and human-related sources to the west.

Following record low water levels in October 1992, a period of water-level rises associated with generally greaterthan-average precipitation and decreased city pumpage from the study area that began in 1993 continued through the current reporting period (January 2006). During January 2006, the direction of ground-water flow in the Equus Beds aquifer in the study area generally was from west to east, which is similar to flow in the aquifer prior to development. Water-level changes since August 1940 for the period January 2003 to January 2006 ranged from a decline of more than $36 \mathrm{ft}$ in July 2004 near the center of the study area to a rise of more than
$2 \mathrm{ft}$ in April 2005 near the northern edge of the study area. Almost all wells in the study area had small cumulative waterlevel rises from January 2003 to January 2006 and larger rises from October 1992 to January 2006. The water-level rises of $10 \mathrm{ft}$ or more from October 1992 to January 2006 probably are due principally to decreases in annual city pumpage from about 36,900 to 23,600 acre-ft, with increases in recharge due to precipitation during the period that averaged about $1.84 \mathrm{in}$. greater than the long-term average as a contributing factor. Another important factor in the decreased city pumpage was increased use of Cheney Reservoir by the city of Wichita as a water-supply source; as a result, city pumpage from the Equus Beds aquifer during 1992-2005 decreased from about 60 to 40 percent of Wichita's usage and was similar to quantities pumped in the late 1940s. Irrigation pumpage increased during the period so it did not contribute to the overall water-level rises for the period.

The storage-volume changes in the study area and in the central part of the study area for the period October 1992 to January 2006 represent recoveries of about 55 and 57 percent, respectively, of storage volume previously lost between August 1940 and October 1992.

No artificial recharge occurred in the study area during the period January 2003 to January 2006. Artificial recharge, which the city of Wichita plans to resume when permitted by State regulations and after completion of Phase I of the Equus Beds Aquifer Storage and Recovery Project in 2006, is expected to cause water levels to rise areally.

\section{References Cited}

Albert, C.D., and Stramel, G.J., 1966, Fluvial sediment in the Little Arkansas River basin, Kansas: U.S. Geological Survey Water-Supply Paper 1798-B, 30 p.

Aucott, W.R., and Myers, N.C., 1998, Changes in groundwater levels and storage in the Wichita well field area, south-central Kansas, 1940-98: U.S. Geological Survey Water-Resources Investigations Report 98-4141, 20 p.

Aucott, W.R., Myers, N.C., and Dague, B.J., 1998, Status of ground-water levels and storage in the Wichita well field area, south-central Kansas, 1997: U.S. Geological Survey Water-Resources Investigations Report 98-4095, 15 p.

Bayne, C.K., 1956, Geology and ground-water resources of Reno County, Kansas: Kansas Geological Survey Bulletin 120, $130 \mathrm{p}$.

Bohling, G.C., and Wilson, B.B., 2004, Statistical and geostatistical analysis of the Kansas High Plains water-table elevations, 2004 measurement campaign: Kansas Geological Survey Open-File Report 2004-57, 39 p. 
Bohling, G.C., and Wilson, B.B., 2005, Statistical and geostatistical analysis of the Kansas High Plains water-table elevations, 2005 measurement campaign: Kansas Geological Survey Open-File Report 2005-6, 43 p.

Bohling, G.C., and Wilson, B.B., 2006, Statistical and geostatistical analysis of the Kansas High Plains water-table elevations, 2006 measurement campaign: Kansas Geological Survey Open-File Report 2006-20, 40 p.

Equus Beds Groundwater Management District No. 2, 1995, Equus Beds Groundwater Management No. 2 management program: Halstead, Kansas, 99 p.

Hansen, C.V., and Aucott, W.R., 2001, Status of ground-water levels and storage volume in the Wichita well field area, south-central Kansas, 1998-2000: U.S. Geological Survey Water-Resources Investigations Report 00-4267, 27 p.

Hansen, C.V., and Aucott, W.R., 2004, Status of ground-water levels and storage volume in the Equus Beds aquifer near Wichita, Kansas, January 2000-January 2003: U.S. Geological Survey Water-Resources Investigations Report 03-4298, 36 p.

Kansas Geological Survey, 2002, WIZARD water well levels database: Kansas Geological Survey, accessed November 7, 2006, at http://www.kgs.ku.edu/Magellan/WaterLevels/ index.html

Laflen, D.R., and Miller, R.D., 2003, 2003 annual water level raw data report for Kansas: Kansas Geological Survey Open-File Report 2003-001, 13 p.

Laflen, D.R., and Miller, R.D., 2004, 2004 annual water level raw data report for Kansas: Kansas Geological Survey Open-File Report 2004-6, 13 p.

Laflen, D.R., and Miller, R.D., 2005, 2005 annual water level data collection report for Kansas: Kansas Geological Survey Open-File Report 2005-55, accessed November 8, 2006, at http://www.kgs.ku.edu/Magellan/WaterLevels/CD/Reports/ OFR05_55/rep00.htm

Lane, C.W., and Miller, D.E., 1965a, Geohydrology of Sedgwick County, Kansas: Kansas Geological Survey Bulletin 176, 100 p.

Lane, C.W., and Miller, D.E., 1965b, Logs of wells and test holes in Sedgwick County, Kansas: Kansas Geological Survey Special Distribution Publication 22, 175 p.

Leonard, R.B., and Kleinschmidt, M.K., 1976, Saline water in the Little Arkansas River Basin area, south-central Kansas: Kansas Geological Survey Chemical Quality Series 3, 24 p.

McGuire, V.L., 2001, Water-level changes in the High Plains aquifer, 1980 to 1999: U.S. Geological Survey Fact Sheet 029-01, 2 p.
McGuire, V.L., 2003, Water-level changes in the High Plains aquifer, predevelopment to 2001, 1999-2000, and 20002001: U.S. Geological Survey Fact Sheet 078-03, 4 p.

McGuire, V.L., 2004a, Water-level changes in the High Plains aquifer, predevelopment to 2002, 1980-2002, and 20012002: U.S. Geological Survey Fact Sheet 2004-3026, 6 p.

McGuire, V.L., 2004b, Water-level changes in the High Plains aquifer, predevelopment to 2003 and 2002 to 2003: U.S. Geological Survey Fact Sheet 2004-3097, 6 p.

McGuire, V.L., and Fischer, B.C., 1999, Water-level changes, 1980 to 1997, and saturated thickness, 1996-97, in the High Plains aquifer: U.S. Geological Survey Fact Sheet 124-99, 4 p.

McGuire, V.L., Johnson, M.R., Schieffer, R.L., Stanton, J.S., Sebree, S.K., and Verstraeten, I.M., 2003, Water in storage and approaches to ground-water management, High Plains aquifer, 2000: U.S. Geological Circular 1243, 51 p.

McGuire, V.L., and Sharpe, J.B., 1997, Water-level changes in the High Plains aquifer-predevelopment to 1995: U.S. Geological Survey Water-Resources Investigations Report 97-4081, 2 sheets, scale 1:2,500,000.

Mitchell, J.E., Woods, John, McClain, T.J., and Buddemeier, R.W., 1993, January 1992 Kansas water levels and data related to water-level changes: Kansas Geological Survey Technical Series 3, 130 p.

Mitchell, J.E., Woods, J.J., McClain, T.J., and Buddemeier, R.W., 1994, January 1993 Kansas water levels and data related to water-level changes: Kansas Geological Survey Technical Series 4, 114 p.

Myers, N.C., Hargadine, G.D., and Gillespie, J.D., 1996, Hydrologic and chemical interaction of the Arkansas River and the Equus Beds aquifer between Hutchinson and Wichita, south-central Kansas: U.S. Geological Survey Water-Resources Investigations Report 95-4191, 100 p.

National Oceanic and Atmospheric Administration, 1998, Climatological data, annual summary, Kansas, 1997: Asheville, North Carolina, v. 111, no. 13, 35 p.

National Oceanic and Atmospheric Administration, 1999, Climatological data, annual summary, Kansas, 1998: Asheville, North Carolina, v. 112, no. 13, 31 p.

National Oceanic and Atmospheric Administration, 2000, Climatological data, annual summary, Kansas, 1999: Asheville, North Carolina, v. 113, no. 13, 35 p.

National Oceanic and Atmospheric Administration, 2001, Climatological data, annual summary, Kansas, 2000: Asheville, North Carolina, v. 114, no. 13, 33 p. 
National Oceanic and Atmospheric Administration, 2002a, Climatological data, annual summary, Kansas, 2001: Asheville, North Carolina, v. 115, no. 13, 36 p.

National Oceanic and Atmospheric Administration, 2002b, Monthly station normals of temperature, precipitation, and heating and cooling degree days, 1971-2000, Kansas: Asheville, North Carolina, Climatography of the United States No. 81,37 p.

National Oceanic and Atmospheric Administration, 2003, Climatological data, annual summary, Kansas, 2002: Asheville, North Carolina, v. 116, no. 13, 32 p.

National Oceanic and Atmospheric Administration, 2004, Climatological data, annual summary, Kansas, 2003: Asheville, North Carolina, v. 117, no. 13, 32 p.

National Oceanic and Atmospheric Administration, 2005a, Climatological data, annual summary, Kansas, 2004: Asheville, North Carolina, v. 118, no. 13, 32 p.

National Oceanic and Atmospheric Administration, 2005b, Daily precipitation data for United States cooperative and National Weather Service sites: Asheville, North Carolina, National Climatic Data Center, accessed February 21, 2006, at http://www.ncdc.noaa.gov/oa/climate/stationlocator.html

Olea, R.A., and Davis, J.C., 2003, Geostatistical analysis and mapping of water-table elevations in the High Plains aquifer of Kansas after the 2003 monitoring season: Kansas Geological Survey Open-File Report 2003-13, 39 p.

Ross, H.C., Myers, N.C., and Aucott, W.R., 1997, Increased use of Cheney Reservoir for Wichita area water supply benefits Equus Beds aquifer: U.S. Geological Survey Fact Sheet 196-97, 2 p.

Schoewe, W.H., 1949, The geography of Kansas, part 2physical geography: Transactions of the Kansas Academy of Science, v. 52, no. 3, p. 261-333.

Spinazola, J.M., Gillespie, J.B., and Hart, R.J., 1985, Groundwater flow and solute transport in the Equus beds area, south-central Kansas: U.S. Geological Survey WaterResources Investigations Report 85-4336, 68 p.

Stallman, R.W., 1971, Aquifer-test design, observation and data analysis: U.S. Geological Survey Techniques of WaterResources Investigations, book 3, chap. B-1, p. 14-16.

Stramel, G.J., 1956, Progress report on the ground-water hydrology of the Equus beds area, Kansas: Kansas Geological Survey Bulletin 119, part 1, 59 p.

Stramel, G.J., 1967, Progress report on the ground-water hydrology of the Equus beds area, Kansas 1966: Kansas Geological Survey Bulletin 187, part 2, 27 p.
Stullken, L.E., Watts, K.R., and Lindgren, R.J., 1985, Geohydrology of the High Plains aquifer, western Kansas: U.S. Geological Survey Water-Resources Investigations Report 85-4198, 86 p.

Theissen, A.H., 1911, Precipitation averages for large areas: Monthly Weather Review, v. 39, p. 1082-1084.

U.S. Geological Survey, 2006, Highlights of Equus Beds Ground-Water Recharge Project: Information available on the Web, accessed November 7, 2006, at http://ks.water. usgs.gov/Kansas/studies/equus/equus_hilites.html

Warren, D.R., Blain, G.T., Shorney, F.L., and Klein, L.J., 1995, IRP — a case study from Kansas: Journal of the American Water Works Association, June 1995, p. 57-71.

Williams, C.C., and Lohman, S.W., 1949, Geology and ground-water resources of a part of south-central Kansas, with special reference to the Wichita municipal water supply: Kansas Geological Survey Bulletin 79, 455 p.

Woods, J.J., Mitchell, J.E., and Buddemeier, R.W., 1994, January 1994 Kansas water levels and data related to water-level changes: Kansas Geological Survey Technical Series 5, $106 \mathrm{p}$.

Woods, J.J., and Schloss, J.A., 1996, January1996 Kansas water levels and data related to water-level changes: Kansas Geological Survey Technical Series 9, 124 p.

Woods, J.J., Schloss, J.A., and Buddemeier, R.W., 1995, January 1995 Kansas water levels and data related to water-level changes: Kansas Geological Survey Technical Series 8, $138 \mathrm{p}$.

Woods, J.J., Schloss, J.A., and Macfarlane, P.A, 1997, January 1997 Kansas water levels and data related to water-level changes: Kansas Geological Survey Technical Series 11, $90 \mathrm{p}$.

Woods, J.J., Schloss, J.A., and Macfarlane, P.A., 1998, January 1998 Kansas water levels and data related to water-level changes: Kansas Geological Survey Technical Series 12, $92 \mathrm{p}$.

Woods, J.J., Schloss, J.A., and Macfarlane, P.A., 1999, January 1999 Kansas water-levels and data related to water-level changes: Kansas Geological Survey Technical Series 14, $89 \mathrm{p}$.

Woods, J.J., Schloss, J.A., and Macfarlane, P.A., 2000, January 2000 Kansas water levels and data related to water-level changes: Kansas Geological Survey Technical Series 15, $89 \mathrm{p}$.

Woods, J.J., and Sophocleous, M.A., 2002, January 2001 Kansas water levels and data related to water-level changes: Kansas Geological Survey Technical Series 17, 95 p. 
Woods, J.J., and Sophocleous, M.A., 2004, January 2002 water levels and data related to water-level changes: Kansas Geological Survey Technical Series 19, 92 p.
Ziegler, A.C., Christensen, V.G., and Ross, H.C., 1999, Baseline water quality and preliminary effects of artificial recharge on ground water, south-central Kansas, 1995-98: U.S. Geological Survey Water-Resources Investigations Report 99-4250, 74 p.

Prepared by Lawrence Publishing Service Center. Edited by Lanna Combs.

Graphics by Michael Kemppainen and Jeff Hartley.

Layout by Michael Kemppainen.

For more information concerning the research described in this report, contact:

U.S. Geological Survey

4821 Quail Crest Place

Lawrence, Kansas 66049-3830

(785) 842-9909

http://ks.water.usgs.gov 


\section{A. Precipitation}

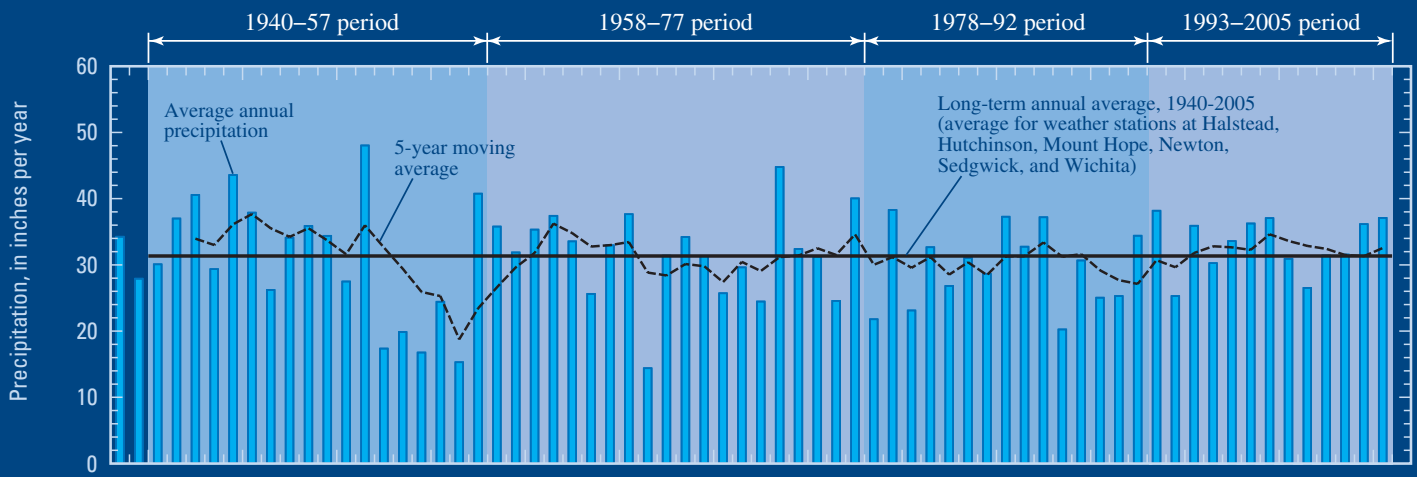

B. Water use for agricultural irrigation and by city of Wichita for public supply

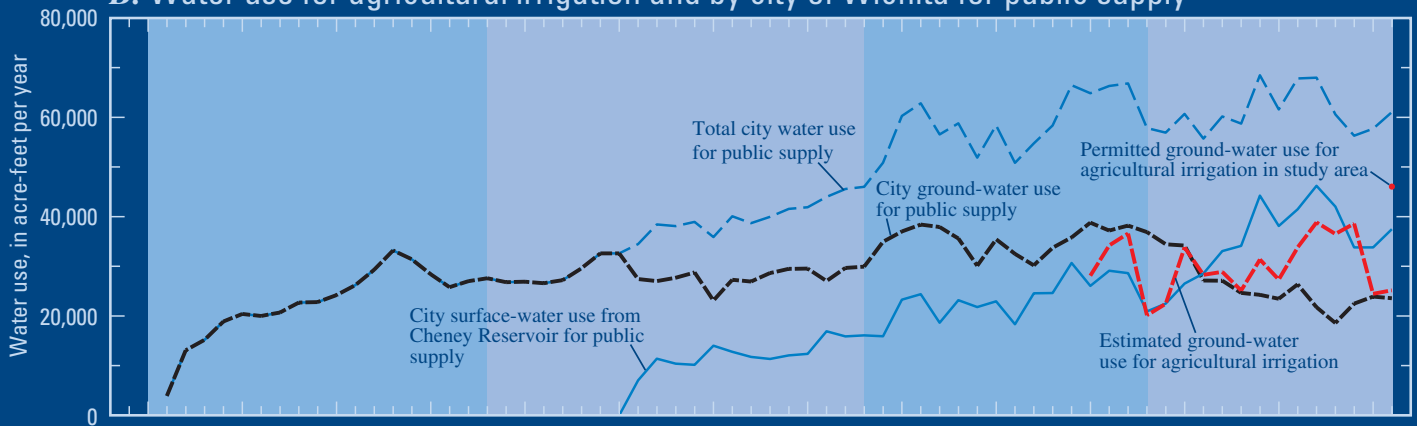

C. Water-level altitudes in observation wells 104 and 886 and Equus Beds aquifer storage-volume change in study area

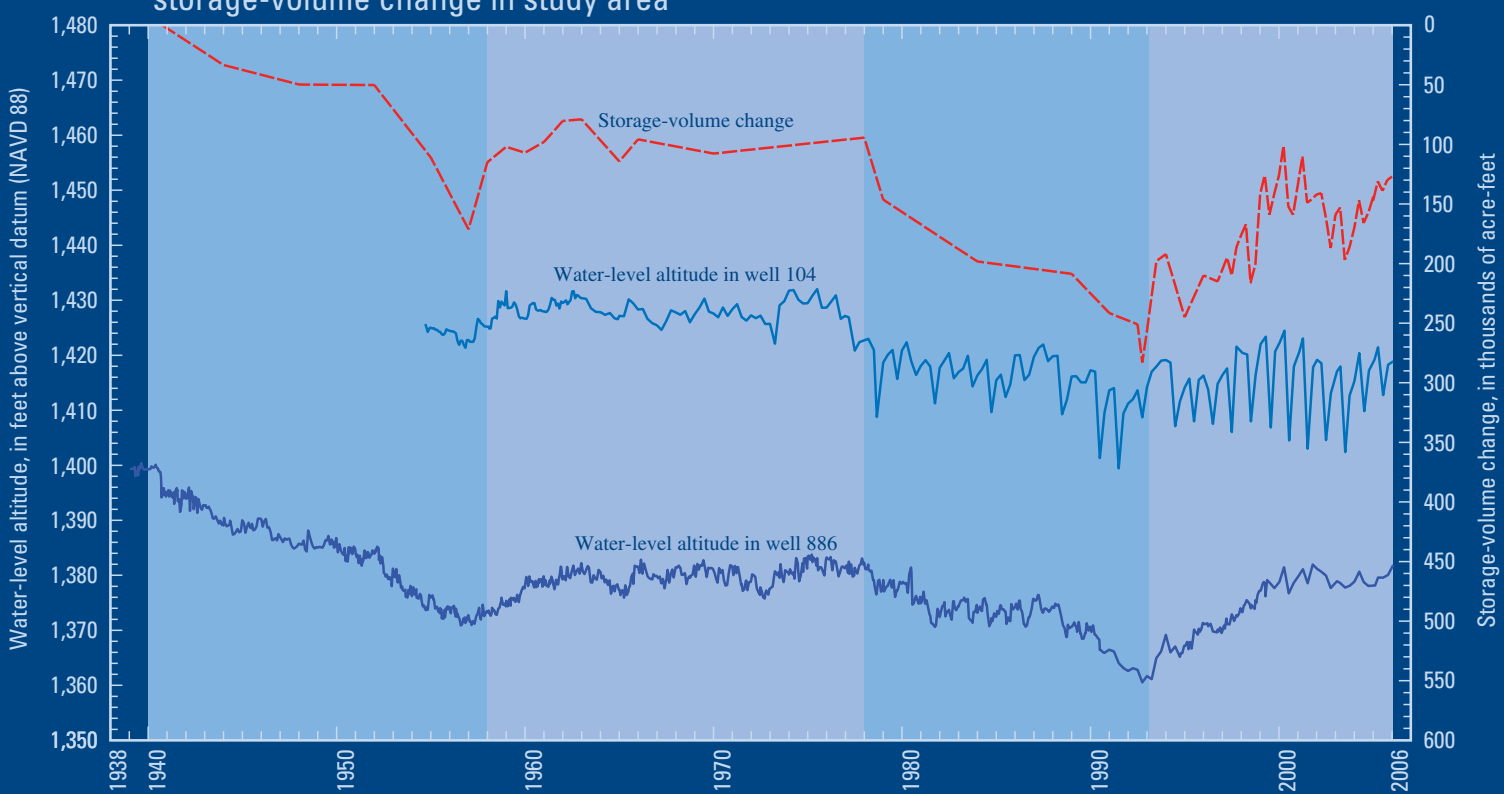

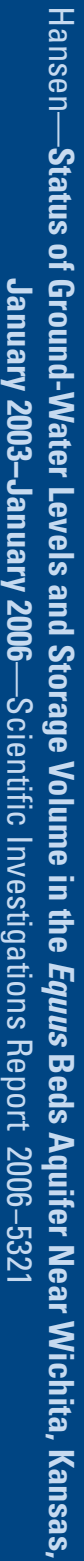

